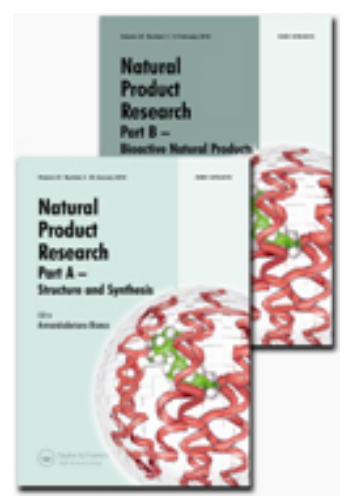

\title{
Prenylated flavonoids and other constituents from Macaranga indica
}

\begin{tabular}{|c|c|}
\hline Journal: & Natural Product Research \\
\hline Manuscript ID & GNPL-2019-1395 \\
\hline Manuscript Type: & Short Communication \\
\hline $\begin{array}{r}\text { Date Submitted by the } \\
\text { Author: }\end{array}$ & 06-Jun-2019 \\
\hline Complete List of Authors: & $\begin{array}{l}\text { Pham, Van Cuong; Institute of Marine Biochemistry, Vietnam Academy of } \\
\text { Science and Technology, } \\
\text { Le, Tran Nguyen Vu; Institute of Marine Biochemistry, Vietnam , } \\
\text { Advanced Center for Bioorganic Chemistry; Graduate University of } \\
\text { Science and Technology, VAST, Faculty of Chemistry } \\
\text { Anh, Luu The; Central Institute for Natural Resources and Environmental } \\
\text { Studies, } \\
\text { Cuc, Nguyen Thi; Institute of Marine Biochemistry } \\
\text { Nhiem, Nguyen Xuan; Vietnam Academy of Science and Technology, } \\
\text { Institute of Marine Biochemistry } \\
\text { Tai, Bui; PhD student, College of Pharmacy } \\
\text { Kiem, Phan; Vietnam Academy of Science and Technology, institute of } \\
\text { Marine Biochemistry } \\
\text { Litaudon, Marc; Institut de Chimie des Substances Naturelles } \\
\text { Tran, Dang Thach; Institute of Applied Science and Technology, } \\
\text { University Industry Vinh } \\
\text { Minh, Chau Van; Institute of Marine Biochemistry, Vietnam academy of } \\
\text { Science and Technology, } \\
\text { Thi Mai, Huong Doan; Institute of Marine Biochemistry - VAST, Organic } \\
\text { Synthesis; }\end{array}$ \\
\hline Keywords: & Macaranga indica, macarindicin, cytotoxic \\
\hline
\end{tabular}

\section{SCHOLARONE $^{\text {m }}$ Manuscripts}



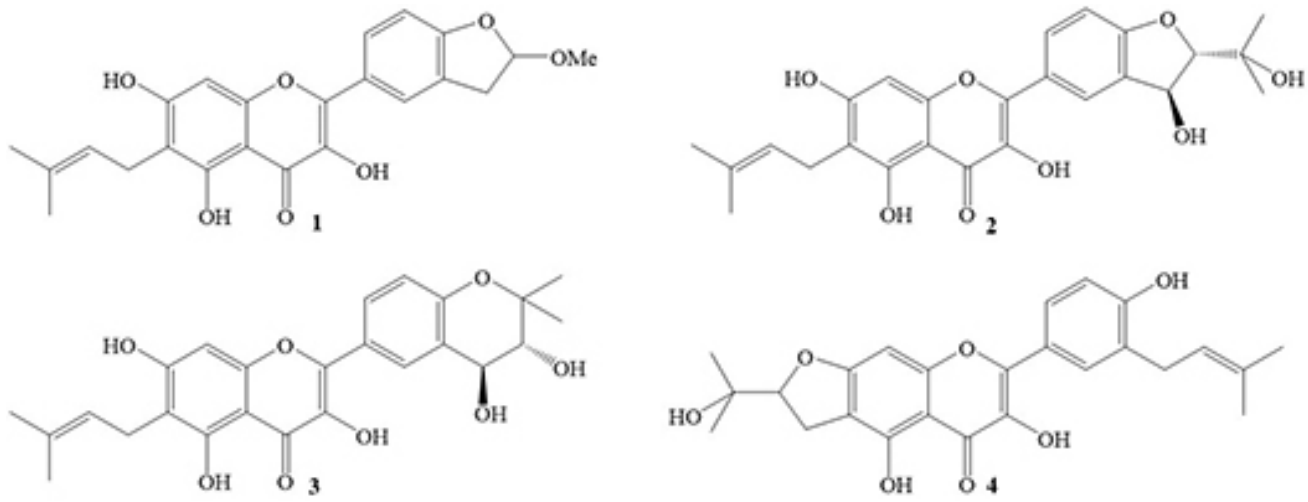

$138 \times 53 \mathrm{~mm}(96 \times 96 \mathrm{DPI})$ 


\section{Prenylated flavonoids and other constituents from Macaranga indica}

Le Tran Nguyen $\mathrm{Vu}^{\mathrm{a}, \mathrm{c}}$, Luu The Anh ${ }^{\mathrm{b}}$, Nguyen Thi Cuc ${ }^{\mathrm{a}, \mathrm{c}}$, Nguyen Xuan Nhiemª, Bui Huu Tai ${ }^{a, c}$, Phan Van Kiemª, ${ }^{\mathrm{a}}$, Marc Litaudon ${ }^{\mathrm{d}}$, Tran Dang Thach ${ }^{\mathrm{e}}$, Chau Van Minh ${ }^{\mathrm{a}}$, Huong Doan Thi Mai ${ }^{\mathrm{a}, \mathrm{c}^{*}}$, and Pham Van Cuong ${ }^{\mathrm{a}, \mathrm{c}^{*}}$

${ }^{a}$ Advanced Center for Bioorganic Chemistry, Institute of Marine Biochemistry (IMBC), Vietnam Academy of Science and Technology (VAST), Cau Giay, Hanoi, Vietnam

${ }^{b}$ Central Institute for Natural Resources and Environmental Studies, Vietnam National University, Hanoi, 19 Le Thanh Tong, Hoan Kiem, Hanoi, Vietnam

${ }^{c}$ Graduate University of Science and Technology, VAST, Cau Giay, Hanoi, Vietnam

${ }^{d}$ Institut de Chimie des Substances Naturelles, CNRS-ICSN, UPR 2301,_Université ParisSaclay, 91198, Gif-sur-Yvette, France

eInstitute of Applied Science and Technology, University Industry Vinh, Vinh, Vietnam

Corresponding Author

\section{Pham Van Cuong, Prof, Ph.D;}

Advanced Center for Bioorganic Chemistry, Institute of Marine Biochemistry, VAST, 18 Hoang Quoc Viet, Cau Giay, Hanoi, Vietnam

E-mail address: phamvc@imbc.vast.vn

\section{Doan Mai Huong Prof, Ph.D;}

Advanced Center for Bioorganic Chemistry, Institute of Marine Biochemistry, VAST, 18 Hoang Quoc Viet, Cau Giay, Hanoi, Vietnam

E-mail address: huongdm@imbc.vast.vn 


\begin{abstract}
Four new prenylated flavonoids, macarindicins I-IV (1-4) together with ten known metabolisms, broussoflavonol F (5), vedelianin (6), schweinfurthin E (7), vitexin (8), 2"-rhamnosyl vitexin (9), isovitexin (10), $(6 R, 7 E, 9 R)-9$-hydroxy-megastigman-4,7-dien-3-one-9- $O-\beta$-Dglucopyranoside (11), 6S,9R)-roseoside (12), $(6 S, 9 S)$-roseoside (13), and bridelionoside B (14) were isolated from the leaves of Macaranga indica. Their structures were determined on the basis of extensive spectroscopic methods, including 1D-, 2D-NMR and MS data. All the isolated compounds were evaluated for their cytotoxic activities against four human cancer cell lines including KB, MCF-7, HepG-2, and LU. As the results, compound 6 significantly exhibited cytotoxic activity against all tested human cancer cell lines with $\mathrm{IC}_{50}$ values ranging from 4.7 to $11.0 \mu \mathrm{M}$. Compounds $\mathbf{2}, \mathbf{5}$, and $\mathbf{7}$ showed moderate cytotoxic activity with $\mathrm{IC}_{50}$ values ranging from 9.0 to $38.7 \mu \mathrm{M}$.
\end{abstract}

Keywords: Macaranga indica, macarindicin, cytotoxic 


\section{Introduction}

The genus Macaranga (Euphorbiaceae) comprises of about 300 species which are mainly distributed in tropics of Africa, Asia, Australia, and the Pacific regions. The Macaranga genus has been used in traditional medicine for the treatments of cuts, bruises, swellings, boils, and sores diseases. Phytochemical investigation of this genus indicated that they are rich source of flavonoids, prenylated flavonoids, geranylated flavonoids, and farnesylated flavonoids (Magadula 2014). Previous phytochemical investigations of $M$. indica led to the isolation and identification of flavonoids and prenylated derivatives (Yang et al. 2015). Herein, we report the isolation and structure elucidation of four new prenylated flavonoids together with ten known compounds from $M$. indica and evaluation of their cytotoxic effects.

\section{Results and discussion}

The methanol extract of $M$. indica was suspended in $\mathrm{H}_{2} \mathrm{O}$ and successively partitioned with $\mathrm{CH}_{2} \mathrm{Cl}_{2}$ and EtOAc to obtain fractions. These fractions were subjected to silica gel, sephadex LH-20, and PR-18 column chromatography to afford four new and ten known compounds (Figure 1).

Compound 1 was obtained as a yellow amorphous powder. Its molecular formula was determined as $\mathrm{C}_{23} \mathrm{H}_{22} \mathrm{O}_{7}$ by HR-ESI-MS at $m / z 411.1438[\mathrm{M}+\mathrm{H}]^{+}$(Calcd. for $\left[\mathrm{C}_{23} \mathrm{H}_{23} \mathrm{O}_{7}\right]^{+}$, 411.1444). The ${ }^{1} \mathrm{H}-\mathrm{NMR}$ spectrum of 1 displayed the presence of four aromatic protons, including an $\mathrm{ABX}$ spin system of B ring at $\delta_{\mathrm{H}} 8.00(1 \mathrm{H}$, br d, $J=8.5 \mathrm{~Hz}), 7.01(1 \mathrm{H}, \mathrm{d}, J=8.5$ $\mathrm{Hz})$, and $8.05(1 \mathrm{H}, \mathrm{d}, J=2.0 \mathrm{~Hz})$; one aromatic proton of A ring at $\delta_{\mathrm{H}} 6.50(1 \mathrm{H}, \mathrm{s})$ suggested the appearence of a flavonol moiety; one olefinic proton at $\delta_{\mathrm{H}} 5.19(1 \mathrm{H}, \mathrm{t}, J=7.0 \mathrm{~Hz})$ and two methyl groups at $\delta_{\mathrm{H}} 1.63(3 \mathrm{H}, \mathrm{s})$ and $1.73(3 \mathrm{H}, \mathrm{s})$ suggested the presence of a prenyl group; and one methoxy proton at $\delta_{\mathrm{H}} 3.45(3 \mathrm{H}, \mathrm{s})$. The ${ }^{13} \mathrm{C}-\mathrm{NMR}$ and HSQC spectra of 1 showed the signals of 23 carbons, including one carbonyl carbon $\left(\delta_{\mathrm{C}} 175.9\right)$, eleven non-protonateds $\left(\delta_{\mathrm{C}} 102.8\right.$, $110.3,123.8,126.3,130.6,135.9,146.3,154.1,157.4,159.0$, and 161.8$)$, six methines $\left(\delta_{\mathrm{C}} 92.8\right.$, 
$108.0,109.4,122.3,124.4$, and 128.3), two methylenes $\left(\delta_{\mathrm{C}} 21.0\right.$ and 35.5), and three methyl carbons at $\left(\delta_{\mathrm{C}} 17.7,25.5\right.$, and 55.4). The ${ }^{1} \mathrm{H}$ and ${ }^{13} \mathrm{C}$ NMR data of 1 were in close agreement with those of glyasperin A (Nomura et al. 1992) except for the B ring of flavonol with the formation of benzofuran ring. This could be the results of oxidation C-7" of the prenyl group at C-3' and then form furan ring. The position of furan ring at C-3' and C-4' was proved by HMBC correlations (Figure S1) from H-5' $\left(\delta_{\mathrm{H}} 7.01\right)$ to $\mathrm{C}-1^{\prime}\left(\delta_{\mathrm{C}} 123.8\right) / \mathrm{C}-3^{\prime}\left(\delta_{\mathrm{C}} 126.3\right)$; from H-6 $\left(\delta_{\mathrm{H}}\right.$ $8.00)$ and $\mathrm{C}-2^{\prime}\left(\delta_{\mathrm{C}} 124.4\right) / \mathrm{C}-4^{\prime}\left(\delta_{\mathrm{C}} 159.0\right) / \mathrm{C}-2\left(\delta_{\mathrm{C}} 146.3\right)$; from H-6" $\left(\delta_{\mathrm{H}} 3.03\right.$ and 3.46$)$ to C-2' $\left(\delta_{\mathrm{C}} 124.4\right) / \mathrm{C}-3^{\prime}\left(\delta_{\mathrm{C}} 126.3\right) / \mathrm{C}-4^{\prime}\left(\delta_{\mathrm{C}} 159.0\right)$; and from H-7" $\left(\delta_{\mathrm{H}} 5.82\right)$ to $\mathrm{C}-3^{\prime}\left(\delta_{\mathrm{C}} 126.3\right) / \mathrm{C}-4^{\prime}\left(\delta_{\mathrm{C}}\right.$ 159.0). In addition, the HMBC correlation between methoxy $\left(\delta_{\mathrm{H}} 3.45\right)$ and C-7" $\left(\delta_{\mathrm{C}} 108.0\right)$ suggested the location of methoxy group at C-7". The HMBC correlations between H-4" $\left(\delta_{\mathrm{H}}\right.$ $1.63) / \mathrm{H}-5 "\left(\delta_{\mathrm{H}} 1.73\right)$ and C-2" $\left(\delta_{\mathrm{C}} 122.3\right) / \mathrm{C}-3 "\left(\delta_{\mathrm{C}} 130.6\right)$ suggested the position of double bond at C-2"/C-3" of the prenyl group. The HMBC correlations between $\mathrm{H}-8\left(\delta_{\mathrm{H}} 6.50\right)$ and C-6 $\left(\delta_{\mathrm{C}}\right.$ $110.3) / \mathrm{C}-7\left(\delta_{\mathrm{C}} 161.8\right) / \mathrm{C}-9\left(\delta_{\mathrm{C}} 154.1\right) / \mathrm{C}-10\left(\delta_{\mathrm{C}} 102.8\right)$ as well as between H-1" $\left(\delta_{\mathrm{H}} 3.24\right)$ and C-5 $\left(\delta_{\mathrm{C}} 157.4\right) / \mathrm{C}-6\left(\delta_{\mathrm{C}} 110.3\right) / \mathrm{C}-7\left(\delta_{\mathrm{C}} 161.8\right)$ suggested the position of prenyl group at C-6 and the hydroxy groups at C-5 and C-7. The specific rotation of $1,[\alpha]_{\mathrm{D}}^{25}=0.0(c 0.1, \mathrm{MeOH})$ together with the detection of Cotton effects in the ECD spectrum (see Supporting information) suggested 1 was a racemic. Consequently, the structure of $\mathbf{1}$ was determined as 6-prenyl-3',4'(2-methoxydihydrofurano)kaempferol and named macarindicin I.

Macarindicin II (2) possessed a molecular formula of $\mathrm{C}_{25} \mathrm{H}_{26} \mathrm{O}_{8}$ as deduced from HR-ESI-MS at $m / z 455.1700[\mathrm{M}+\mathrm{H}]^{+}\left(\mathrm{Calcd}\right.$. for $\left.\left[\mathrm{C}_{25} \mathrm{H}_{27} \mathrm{O}_{8}\right]^{+}, 455.1706\right)$. The ${ }^{1} \mathrm{H}-\mathrm{NMR}$ spectrum of 2 showed the signals of three ABX aromatic protons of B ring at $\delta_{\mathrm{H}} 6.98(1 \mathrm{H}, \mathrm{d}, J=9.0 \mathrm{~Hz}), 8.16$ $(1 \mathrm{H}, \mathrm{dd}, J=2.0,9.0 \mathrm{~Hz})$, and $8.28(1 \mathrm{H}, \mathrm{d}, J=2.0 \mathrm{~Hz})$, one singlet aromatic proton of A ring at $\delta_{\mathrm{H}} 6.46(1 \mathrm{H}, \mathrm{s})$, assigned to flavonol moiety; one olefinic proton at $\delta_{\mathrm{H}} 5.26(1 \mathrm{H}, \mathrm{t}, J=6.5$ $\mathrm{Hz})$, two oxygenated methines at $\delta_{\mathrm{H}} 4.35(\mathrm{~d}, J=4.0 \mathrm{~Hz})$ and $5.41(\mathrm{~d}, J=4.0 \mathrm{~Hz})$; four methyl groups at $\delta_{\mathrm{H}} 1.39(6 \mathrm{H}, \mathrm{s}), 1.69(3 \mathrm{H}, \mathrm{s})$, and $1.81(3 \mathrm{H}, \mathrm{s})$ suggested the appearance of two prenyl 
groups. The ${ }^{13} \mathrm{C}-\mathrm{NMR}$ and HSQC spectra of 2 showed the signals of 25 carbons, including one carbonyl, twelve non-protonateds, seven methines, one methylene, and four methyl carbons. The analysis of the 1D and 2D-NMR spectra indicated the strucutre of $\mathbf{2}$ as diprenylated flavonol. The first prenyl moiety was located at C-6 of flavonol, similar to those of $\mathbf{1}$ and also confirmed by the HMBC correlations between H-1" $\left(\delta_{\mathrm{H}} 3.34\right)$ and C-5 $\left(\delta_{\mathrm{C}} 159.1\right) / \mathrm{C}-6\left(\delta_{\mathrm{C}}\right.$ $112.3) / \mathrm{C}-7\left(\delta_{\mathrm{C}} 163.5\right)$. The HMBC correlations between H-6" $\left(\delta_{\mathrm{H}} 5.41\right)$ and C-2' $\left(\delta_{\mathrm{C}} 126.5\right) / \mathrm{C}-3^{\prime}$ $\left(\delta_{\mathrm{C}} 131.3\right) \mathrm{C}-4^{\prime}\left(\delta_{\mathrm{C}} 163.0\right) / \mathrm{C}-7^{\prime \prime}\left(\delta_{\mathrm{C}} 98.8\right)$ suggested the position second prenyl group at C-3' The five member cyclization of prenyl group with B ring of flavonol via oxy-bridge at C-4' and C-8" was confirmed by the HMBC correlations from H-7" $\left(\delta_{\mathrm{H}} 4.35\right)$ to $\mathrm{C}-3^{\prime}\left(\delta_{\mathrm{C}} 131.3\right) / \mathrm{C}-4^{\prime}\left(\delta_{\mathrm{C}}\right.$ 163.0). Two hydroxy groups were located at C-6" and C-8" as the results of HMBC correlations from $\mathrm{H}-2^{\prime}\left(\delta_{\mathrm{H}} 8.05\right)$ to $\mathrm{C}-6 "\left(\delta_{\mathrm{C}} 73.6\right)$; from $\mathrm{H}-9^{\prime \prime} / 10^{\prime \prime}\left(\delta_{\mathrm{H}} 1.31\right)$ to $\mathrm{C}-7 "\left(\delta_{\mathrm{C}} 98.8\right) / \mathrm{C}-8^{\prime \prime}\left(\delta_{\mathrm{C}} 71.9\right)$. The small coupling constant between $\mathrm{H}-6^{\prime \prime}$ and $\mathrm{H}-77^{\prime \prime}, J=4.0 \mathrm{~Hz}$ as well as NOESY correlations between $\mathrm{H}-6 " 6^{\prime \prime}\left(\delta_{\mathrm{H}} 5.41\right)$ and $\mathrm{H}-9^{\prime \prime} / 10^{\prime \prime}\left(\delta_{\mathrm{H}} 1.31\right)$ suggested the configuration of dihyrofuran as

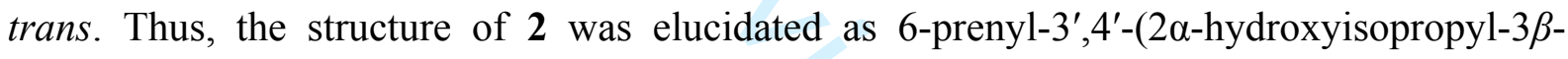
hydroxydihydrofurano)kaempferol and named macarindicin II, a racemic due to the observation of no Cotton effect and specific optical ratation.

HR-ESI-MS experiments of $\mathbf{3}$ resulted in the same molecular formula as that of $\mathbf{2}$ (see Experimental). The analysis of ${ }^{1} \mathrm{H}-$ and ${ }^{13} \mathrm{C}-\mathrm{NMR}$ data suggested the structure 3 was diprenylated flavonol. The structure of $\mathbf{3}$ was similar to those of $\mathbf{2}$ except for a little difference of second prenyl moiety at B ring of flavonol. The HMBC correlations between H-6" $\left(\delta_{\mathrm{H}} 4.41\right)$ and C-2' $\left(\delta_{\mathrm{C}} 128.3\right) / \mathrm{C}-3^{\prime}\left(\delta_{\mathrm{C}} 125.7\right) / \mathrm{C}-4^{\prime}\left(\delta_{\mathrm{C}} 153.6\right) / \mathrm{C}-8^{\prime \prime}\left(\delta_{\mathrm{C}} 79.0\right)$ proved the positions of two hydroxy groups at C-6" and C-7". The dihydropyran ring was established between C-6"/C-7"/C$8^{\prime \prime}$ of prenyl and C-3' and C-4' of flavonol based on the shift to low field of C-4' $\left(\delta_{\mathrm{C}} 153.6\right)$ and high field C-8" $\left(\delta_{\mathrm{C}} 79.4\right)$ and HR-ESI-MS. Moreover, the trans configuration of two hydroxy groups of dihydropyran were determined by large coupling constant between H-6" and H-7", $J$ 
$=7.5 \mathrm{~Hz}$. Consequently, the strucutre of $\mathbf{3}$ was elucidated as 6-prenyl-3',4'-(2,2-dimethyl$3 \alpha, 4 \beta$-dihydroxydihydropyrano)kaempferol and named as macarindicin III.

The molecular formula of macarindicin IV (4) was deduced to be $\mathrm{C}_{25} \mathrm{H}_{26} \mathrm{O}_{7}$ based on its HRESI-MS at $\mathrm{m} / \mathrm{z} m / z: 439.1750[\mathrm{M}+\mathrm{H}]^{+}\left(\mathrm{Calcd}\right.$. for $\left.\left[\mathrm{C}_{25} \mathrm{H}_{27} \mathrm{O}_{7}\right]^{+}, 439.1757\right)$. The ${ }^{1} \mathrm{H}-$ and ${ }^{13} \mathrm{C}-$ NMR data suggested the structure of $\mathbf{4}$ was diprenylated flavonol, similar to those of $\mathbf{2}$ with the difference of two prenyl exist forms. First prenyl moiety at C-6 was confirmed by first prenyl moiety at C-3' and second prenyl with the exist of dihydrofuran ring at C-6 and C-7 of flavonol. The location of prenyl group at C-3' of flavonol was confirmed by the HMBC correlations between H-6" $\left(\delta_{\mathrm{H}} 3.29\right)$ and C-2' $\left(\delta_{\mathrm{C}} 129.1\right) / \mathrm{C}-3^{\prime}\left(\delta_{\mathrm{C}} 127.7\right) / \mathrm{C}-4^{\prime}\left(\delta_{\mathrm{C}} 156.9\right)$. The HMBC correlations between H-1" $\left(\delta_{\mathrm{H}} 3.08\right)$ and C-5 $\left(\delta_{\mathrm{C}} 154.7\right) / \mathrm{C}-6\left(\delta_{\mathrm{C}} 108.3\right) / \mathrm{C}-7\left(\delta_{\mathrm{C}} 166.1\right)$ and between H-2" and C-6 $\left(\delta_{\mathrm{C}} 108.3\right) / \mathrm{C}-7\left(\delta_{\mathrm{C}} 166.1\right) / \mathrm{C}-4 "\left(\delta_{\mathrm{C}} 24.8\right) / \mathrm{C}-5^{\prime \prime}\left(\delta_{\mathrm{C}} 25.8\right)$ suggested the position of dihydrofurano ring at C-6/C-7 of the flavonol and 2-hydroxyisopropyl at C-2 of the dihydrofurano group. Compound $\mathbf{4}$ was deteremined as racemic due to its specific optical roation, $[\alpha]_{\mathrm{D}}{ }^{25}=0.0(c 0.1, \mathrm{MeOH})$ and no Cotton effect on the $\mathrm{CD}$ spectrum. Based on the above evidence, the structure of 4 was elucidatded as 3'-prenyl-6,7-(2hydroxyisopropyldihydrofurano)kaempferol and named macarindicin IV.

The known compounds, broussoflavonol F (5) (Fang et al. 1995), vedelianin (6) (Yoder et al. 2007), schweinfurthin E (7) (Yoder et al. 2007), vitexin (8) (Cuong et al. 2015), 2"-rhamnosyl vitexin (9), isovitexin (10) (Cuong et al. 2015), (6R,7E,9R)-9-hydroxy-megastigman-4,7-dien3-one-9-O- $\beta$-D-glucopyranoside (11), 6S,9R)-roseoside (12) (Trang et al. 2016), (6S,9S)roseoside (13) (Çalış et al. 2002), and bridelionoside B (14) (Sueyoshi et al. 2006) were identified by comparison of their NMR data with those reported in the literature.

Since prenylated flavonoids are reported to have modest or significant anticancer activities (Chen et al. 2014). The cytotoxicity of all isolated compounds were evaluated against KB, MCF-7, HepG-2, and LU human cancer cell lines (Table 1). As the results, compound 6 
significantly exhibited cytotoxicity against all tested human cancer cell lines with $\mathrm{IC}_{50}$ values ranging from 4.7 to $11.0 \mu \mathrm{M}$. Compounds $\mathbf{2}, \mathbf{5}$, and 7 showed moderate cytotoxic activity with $\mathrm{IC}_{50}$ values ranging from 9.0 to $38.7 \mu \mathrm{M}$. The remaining compounds did not show cytotoxic activity $\left(\mathrm{IC}_{50}>100 \mu \mathrm{M}\right)$. These results suggest that discovery of vedelianin may increase the possibility of finding new anticancer agents. The mechanism of action of the $\mathbf{1}$ from this plant or other sources need to be further studied.

\section{Experimental}

\subsection{General}

All NMR spectra were recorded on a Bruker 500 MHz. HR-ESI-MS spectra were obtained using an AGILENT 6550 iFunnel Q-TOF LC/MS system. Column chromatography (CC) was performed on silica-gel (Kieselgel 60, 70-230 mesh and 230-400 mesh, Merck) or RP-18 resins (30 - $50 \mu \mathrm{m}$, Fuji Silysia Chemical Ltd.). For thin layer chromatography (TLC), pre-coated silica-gel 60 F254 (0.25 mm, Merck) and RP-18 F254S (0.25 mm, Merck) plates were used.

\subsection{Plant material}

The leaves of M. indica were collected at Huong Hoa, Quangtri, Vietnam in August 2010 and identified by Dr. Nguyen The Cuong, Institute of Ecology and Biological Resources, VAST. A voucher specimen (MI1008) was deposited at the Institute of Marine Biochemistry, VAST.

\subsection{Extraction and isolation}

The dried leaves of $M$. indica $(1.92 \mathrm{~kg})$ were sonicated with hot $\mathrm{MeOH}$ three times $(3 \times 6 \mathrm{~L})$ to yield $155 \mathrm{~g}$ extract after evaporation of the solvent. This extract was suspended in $\mathrm{H}_{2} \mathrm{O}$ and successively partitioned with $\mathrm{CH}_{2} \mathrm{Cl}_{2}$ and EtOAc to obtain the $\mathrm{CH}_{2} \mathrm{Cl}_{2}(\mathrm{MI} 1,88.0 \mathrm{~g})$ and EtOAc (MI2, $16.0 \mathrm{~g}$ ) extracts and $\mathrm{H}_{2} \mathrm{O}$ (MI3) layer after removal of the solvents in vacuo.

The MI1 fraction was chromatographed on a silica gel column eluting with a gradient of $\mathrm{CH}_{2} \mathrm{Cl}_{2} / \mathrm{MeOH} \quad(100 / 0 \rightarrow 2.5 / 1)$ to give five fractions, MI1A-MI1E. MI1B was chromatographed on a RP-18 column eluting with acetone/water $(2.5 / 1, \mathrm{v} / \mathrm{v})$ to give four 
fractions, MI1B1-MI1B4. MI1B2 was chromatographed on a silica gel column eluting with $\mathrm{CH}_{2} \mathrm{Cl}_{2} / \mathrm{MeOH}(60 / 1, \mathrm{v} / \mathrm{v})$ to give three fractions, MI1B2A-MI1B2C. MI1B2A was chromatographed on a Sephadex LH-20 column eluting with $\mathrm{MeOH} /$ water $(1 / 1, \mathrm{v} / \mathrm{v})$ to give $\mathbf{1}$ (14.0 mg). MI1B2C was chromatographed on a silica gel column eluting with $n$-hexane/EtOAc $(3 / 1, \mathrm{v} / \mathrm{v})$ to yield $4(11.0 \mathrm{mg})$. MI1B4 was chromatographed on a silica gel column eluting with $\mathrm{CH}_{2} \mathrm{Cl}_{2} / \mathrm{EtOAc}(20 / 1, \mathrm{v} / \mathrm{v})$ to give two smaller fractions, MI1B4A-MI1B4B. Compound 5 (23.0 $\mathrm{mg})$ was obtained from MI1B4B on a silica gel column using $n$-hexane/EtOAc $(6 / 1, \mathrm{v} / \mathrm{v})$ as the eluent. The MI1D was chromatographed on silica gel column eluting with $n$-hexane/acetone $(2 / 1, \mathrm{v} / \mathrm{v})$ to give four fractions, MI1D1-MI1D4. MI1D1 was chromatographed on a silica gel column eluting with $\mathrm{CH}_{2} \mathrm{Cl}_{2} / \mathrm{MeOH}(15 / 1, \mathrm{v} / \mathrm{v})$ to give two fractions, MID1A-MI1D1B. MID1A was chromatographed on a sephadex LH-20 column eluting with $\mathrm{MeOH} /$ water (1/1, v/v) to yield compounds $6(14.0 \mathrm{mg})$ and $7(5.0 \mathrm{mg})$. MI1D3 was chromatographed on a silica gel column eluting with $n$-hexane/EtOAc $(1 / 1, \mathrm{v} / \mathrm{v})$ to give two fractions, MI1D3A-MI1D3B. Compounds $2(5.0 \mathrm{mg})$ and $\mathbf{3}(7.0 \mathrm{mg})$ were obtained from MI1D3B on a silica gel column using $\mathrm{CH}_{2} \mathrm{Cl}_{2} / \mathrm{MeOH}(20 / 1, \mathrm{v} / \mathrm{v})$. MI1E was chromatographed on a RP-18 column eluting with acetone/water (2/1, v/v) to give three fractions, MI1E1-MI1E3. MI1E1 was chromatographed on a silica gel column eluting with EtOAc/MeOH $(7 / 1, \mathrm{v} / \mathrm{v})$ to give two fractions, MI1E1AMI1E1B. MI1E1A was chromatographed on a RP-18 column eluting with $\mathrm{MeOH} /$ water (1/1, $\mathrm{v} / \mathrm{v})$ to yield $10(7.0 \mathrm{mg})$. Compound $9(16.0 \mathrm{mg})$ was obtained from MI1E1B on a silica gel column using $\mathrm{CH}_{2} \mathrm{Cl}_{2} / \mathrm{MeOH}(5 / 1, \mathrm{v} / \mathrm{v})$ as eluent. MI1E2 was chromatographed on a silica gel column eluting with $\mathrm{CH}_{2} \mathrm{Cl}_{2} / \mathrm{MeOH}(5 / 1, \mathrm{v} / \mathrm{v})$ to give two fractions, MIE2A-MIE2B. Compound 8 (8.0 $\mathrm{mg})$ was obtained from MIE2B on a silica gel column eluting with $\operatorname{EtOAc} / \mathrm{MeOH}(8 / 1, \mathrm{v} / \mathrm{v})$.

The MI2 fraction was chromatographed on a silica gel column eluting with a gradient of $\mathrm{CH}_{2} \mathrm{Cl}_{2} / \mathrm{MeOH} \quad(40 / 1 \rightarrow 1 / 1)$ to give four smaller fractions, MI2A-MI2D. MI2C was 
chromatographed on a RP-18 column eluting with acetone/water $(1 / 2, \mathrm{v} / \mathrm{v})$ to give three fractions, MI2C1-MI2C3. Compound $11(11.0 \mathrm{mg})$ was obtained from MI2C2 on a silica gel column eluting with EtOAc/MeOH (8/1, v/v).

The MI3 was chromatographed on a Diaion HP-20 column, first eluting with water to remove sugar components, then increasing concentration of $\mathrm{MeOH}$ in water $(50,75$, and $100 \%)$ to obtain three fractions, MI3A-MI3C. The MI3A fraction was chromatographed on a silica gel column eluting with a gradient of $\mathrm{CH}_{2} \mathrm{Cl}_{2} / \mathrm{MeOH}(10 / 1 \rightarrow 0 / 1)$ to give four fractions, MI3A1MI3A4. MI3A1 was chromatographed on a RP-18 column eluting with MeOH/water (1/2, v/v) to give three fractions, MI3A1A-MI3A1C. Compound $14(8.0 \mathrm{mg})$ was obtained from MI3A1B on a silica gel column, using EtOAc/MeOH (5/1, v/v). MI3A1C was chromatographed on a silica gel column eluting with EtOAc/MeOH (8/1, v/v) to yield compounds $12(15.0 \mathrm{mg})$ and $13(10.5 \mathrm{mg})$.

\subsubsection{Macarindicin I (1)}

Yellow amorphous powder; $\mathrm{C}_{23} \mathrm{H}_{22} \mathrm{O}_{7}$; HR-ESI-MS m/z: $411.1438[\mathrm{M}+\mathrm{H}]^{+}$(Calcd. for $\left.\left[\mathrm{C}_{23} \mathrm{H}_{23} \mathrm{O}_{7}\right]^{+}, 411.1444\right) ;{ }^{1} \mathrm{H}-\mathrm{NMR}\left(\mathrm{DMSO}-\mathrm{d}_{6}, 500 \mathrm{MHz}\right) \delta_{\mathrm{H}}: 6.50$ (s, H-6), 8.05 (br s, H-2'), 7.01 (d, $\left.J=8.5 \mathrm{~Hz}, \mathrm{H}-5^{\prime}\right), 8.00$ (br d, $\left.J=8.5 \mathrm{~Hz}, \mathrm{H}-6^{\prime}\right), 3.24$ (d, $\left.J=7.0 \mathrm{~Hz}, \mathrm{H}-1^{\prime \prime}\right), 5.19$ (t, $J=7.0 \mathrm{~Hz}$, H-2"), 1.63 (s, H-4"), 1.73 (s, H-5"), 3.03 (br d, $J=17.0 \mathrm{~Hz}, \mathrm{H}_{\mathrm{a}}-6^{\prime \prime} 3.46$ (dd, J=5.5, $17.0 \mathrm{~Hz}, \mathrm{H}_{\mathrm{b}^{-}}$ $\left.6^{\prime \prime}\right), 5.82$ (br d, $\left.J=5.5 \mathrm{~Hz}, \mathrm{H}-7^{\prime \prime}\right)$, and 3.45 (s, 7-OMe); ${ }^{13} \mathrm{C}-\mathrm{NMR}$ (DMSO-d $\left.6,125 \mathrm{MHz}\right) \delta_{\mathrm{C}}$ : 146.3 (C-2), 135.9 (C-3), 175.9 (C-4), 157.4 (C-5), 110.3 (C-6), 161.8 (C-7), 92.8 (C-8), 154.1 (C-9), 102.8 (C-10), 123.8 (C-1'), 124.4 (C-2'), 126.3 (C-3'), $159.0\left(\mathrm{C}^{\prime} 4^{\prime}\right), 109.4\left(\mathrm{C}-5^{\prime}\right), 128.3$ (C6'), 21.0 (C-1"), 122.3 (C-2"), 130.6 (C-3"), 25.5 (C-4"), 17.7 (C-5"), 35.5 (C-6"), 108.0 (C-7"), and 55.4 (7"-OMe).

\subsubsection{Macarindicin II (2)}

Yellow amorphous powder; $\mathrm{C}_{25} \mathrm{H}_{26} \mathrm{O}_{8}$; HR-ESI-MS m/z: $455.1700[\mathrm{M}+\mathrm{H}]^{+}$(Calcd. for $\left.\left[\mathrm{C}_{25} \mathrm{H}_{27} \mathrm{O}_{8}\right]^{+}, 455.1706\right) ;{ }^{1} \mathrm{H}-\mathrm{NMR}\left(\mathrm{CD}_{3} \mathrm{OD}, 500 \mathrm{MHz}\right) \delta_{\mathrm{H}}: 6.46(\mathrm{~s}, \mathrm{H}-6), 8.28(\mathrm{~d}, J=2.0 \mathrm{~Hz}, \mathrm{H}-$ $\left.2^{\prime}\right), 6.98\left(\mathrm{~d}, J=9.0 \mathrm{~Hz}, \mathrm{H}-5^{\prime}\right), 8.16$ (dd, $\left.J=2.0,9.0 \mathrm{~Hz}, \mathrm{H}-6^{\prime}\right), 3.34$ (d, $\left.J=6.5 \mathrm{~Hz}, \mathrm{H}-1^{\prime \prime}\right), 5.26$ (t, $\left.J=6.5 \mathrm{~Hz}, \mathrm{H}-2^{\prime \prime}\right), 1.69$ (s, H-4"), 1.81 (s, H-5"), 5.41 (d, $\left.J=4.0 \mathrm{~Hz}, \mathrm{H}-6^{\prime \prime}\right), 4.35$ (d, J = $4.0 \mathrm{~Hz}$, H-7"), 1.31 (s, H-9"), and 1.31 (s, H-10"); ${ }^{13} \mathrm{C}-\mathrm{NMR}\left(\mathrm{CD}_{3} \mathrm{OD}, 125 \mathrm{MHz}\right) \delta_{\mathrm{C}}: 147.4(\mathrm{C}-2), 137.3$ (C-3), 177.4 (C-4), 159.1 (C-5), 112.3 (C-6), 163.5 (C-7), 93.7 (C-8), 156.2 (C-9), 104.4 (C-10), 
$125.5\left(\mathrm{C}-1^{\prime}\right), 126.5\left(\mathrm{C}-2^{\prime}\right), 131.3\left(\mathrm{C}-3^{\prime}\right), 163.0\left(\mathrm{C}-4^{\prime}\right), 110.9\left(\mathrm{C}-5^{\prime}\right), 131.4\left(\mathrm{C}-6^{\prime}\right), 22.2$ (C-1"), 123.5 (C-2"), 132.0 (C-3"), 25.9 (C-4"), 17.9 (C-5"), 73.6 (C-6"), 98.8 (C-7"), 71.9 (C-8"), 25.4 $\left(\mathrm{C}-9^{\prime \prime}\right)$, and $25.4\left(\mathrm{C}-10^{\prime \prime}\right)$.

\subsubsection{Macarindicin III (3)}

Yellow amorphous powder; $\mathrm{C}_{25} \mathrm{H}_{26} \mathrm{O}_{8} ; \mathrm{HR}$-ESI-MS m/z: $455.1698[\mathrm{M}+\mathrm{H}]^{+}(\mathrm{Calcd}$. for $\left.\left[\mathrm{C}_{25} \mathrm{H}_{27} \mathrm{O}_{8}\right]^{+}, 455.1706\right)$; ${ }^{1} \mathrm{H}-\mathrm{NMR}\left(\mathrm{DMSO}_{6}, 500 \mathrm{MHz}\right) \delta_{\mathrm{H}}: 6.49$ (s, H-6), 8.26 (d, $J=2.0 \mathrm{~Hz}$, H-2'), 6.87 (d, $\left.J=9.0 \mathrm{~Hz}, \mathrm{H}-5^{\prime}\right), 7.96$ (dd, $\left.J=2.0,9.0 \mathrm{~Hz}, \mathrm{H}-6^{\prime}\right), 3.24$ (d, $\left.J=7.0 \mathrm{~Hz}, \mathrm{H}-1^{\prime \prime}\right)$, 5.19 (t, $J=7.0$ Hz, H-2"), 1.63 (s, H-4"), 1.73 (s, H-5"), 4.41 (t, $J=7.5$ Hz, H-6"), 3.42 (dd, $J$ $\left.=4.5,7.5 \mathrm{~Hz}, \mathrm{H}-7^{\prime \prime}\right), 1.40$ (s, H-9"), 1.17 (s, H-10"); ${ }^{13} \mathrm{C}-\mathrm{NMR}\left(\mathrm{DMSO}-\mathrm{d}_{6}, 125 \mathrm{MHz}\right) \delta_{\mathrm{C}}: 146.2$ (C-2), 135.9 (C-3), 175.9 (C-4), 157.4 (C-5), 110.2 (C-6), 161.8 (C-7), 92.7 (C-8), 154.0 (C-9), 102.8 (C-10), 122.9 (C-1'), 128.3 (C-2'), 125.7 (C-3'), 153.6 (C-4'), 116.2 (C-5'), 128.2 (C-6'), 21.0 (C-1"), 122.2 (C-2"), 130.6 (C-3"), 25.4 (C-4"), 17.7 (C-5"), 67.6 (C-6"), 74.4 (C-7"), 79.4 (C-8"), $26.6\left(\mathrm{C}-9^{\prime \prime}\right)$, and $19.6\left(\mathrm{C}-10^{\prime \prime}\right)$.

\subsubsection{Macarindicin IV (4)}

Yellow amorphous powder; $\mathrm{C}_{25} \mathrm{H}_{26} \mathrm{O}_{7}$; HR-ESI-MS m/z: $439.1750[\mathrm{M}+\mathrm{H}]^{+}$(Calcd. for $\left.\left[\mathrm{C}_{25} \mathrm{H}_{27} \mathrm{O}_{7}\right]^{+}, 439.1757\right) ;{ }^{1} \mathrm{H}-\mathrm{NMR}\left(\mathrm{DMSO}_{6}, 500 \mathrm{MHz}\right) \delta_{\mathrm{H}}: 6.54(\mathrm{~s}, \mathrm{H}-6), 7.94$ (d, J = $2.0 \mathrm{~Hz}$, H-2'), 6.94 (d, $\left.J=8.5 \mathrm{~Hz}, \mathrm{H}-5^{\prime}\right), 7.89$ (dd, $\left.J=2.0,8.5 \mathrm{~Hz}, \mathrm{H}-6^{\prime}\right), 3.08$ (d, $\left.J=8.0 \mathrm{~Hz}, \mathrm{H}-1^{\prime \prime}\right), 4.76$ (t, $\left.J=8.0 \mathrm{~Hz}, \mathrm{H}-2^{\prime \prime}\right), 1.17$ (s, H-4"), 1.16 (s, H-5"), 3.29 (d, $\left.J=7.5 \mathrm{~Hz}, \mathrm{H}-6^{\prime \prime}\right), 5.31$ (t, $J=7.5 \mathrm{~Hz}$, H-7"), 1.71 (s, H-9"), and 1.71 (s, H-10"); ${ }^{13} \mathrm{C}-\mathrm{NMR}$ (DMSO-d 6 , $\left.125 \mathrm{MHz}\right) \delta_{\mathrm{C}}: 147.0$ (C-2), 135.0 (C-3), 176.0 (C-4), 154.7 (C-5), 108.3 (C-6), 166.1 (C-7), 88.3 (C-8), 156.0 (C-9), 103.9 (C10), $121.6\left(\mathrm{C}-1^{\prime}\right), 129.1$ (C-2'), 127.7 (C-3'), 156.9 (C-4'), 114.9 (C-5'), 126.9 (C-6'), 25.9 (C1"), 91.4 (C-2"), 70.0 (C-3"), 24.8 (C-4"), 25.8 (C-5"), 28.1 (C-6"), 122.4 (C-7"), 131.8 (C-8"), $25.5\left(\mathrm{C}-9^{\prime \prime}\right)$, and $17.7\left(\mathrm{C}-10^{\prime \prime}\right)$.

3.4. Cytotoxicity assay: see reference (Thu et al. 2015)

\section{Disclosure statement}

No potential conflict of interest was reported by the authors.

\section{Funding}

The Ministry of Science and Technology of Vietnam for financial support [Grant number ĐTĐLCN.14/16] and the Centre National de la Recherche Scientifique (CNRS, France) is gratefully acknowledged for the Franco-Vietnamese Cooperation Program. 


\section{REFERENCES}

Çalış İ, Kuruüzüm-Uz A, Lorenzetto PA, Rüedi P. 2002. (6S)-Hydroxy-3-oxo- $\alpha-$ ionol glucosides from Capparis spinosa fruits. Phytochemistry. 59(4):451-457.

Chen X, Mukwaya E, Wong M-S, Zhang Y. 2014. A systematic review on biological activities of prenylated flavonoids. Pharm Biol. 52(5):655-660.

Cuong LCV, Trang DT, Cuc NT, Nhiem NX, Yen PH, Anh HLT, Huong LM, Minh CV, Kiem PV. 2015. Flavonoid glycosides from Antidesma ghaesembilla. Vietnam Journal of Chemistry. 53(2e):94-97.

Fang S-C, Shieh B-J, Wu R-R, Lin C-N. 1995. Isoprenylated flavonols of formosan Broussonetia papyrifera. Phytochemistry. 38(2):535-537.

Magadula JJ. 2014. Phytochemistry and pharmacology of the genus Macaranga: A review. J Med Plant Res. 8:489-503.

Nomura T, Zeng L, Fukai T, Zhang R-Y, Lou Z-C. 1992. Four new prenylated flavonoids, glyasperins A, B, C, and D from the roots of Glycyrrhiza aspera. Heterocycles. 34(3):575-587. Sueyoshi E, Liu H, Matsunami K, Otsuka H, Shinzato T, Aramoto M, Takeda Y. 2006. Bridelionosides A-F: Megastigmane glucosides from Bridelia glauca f. balansae. Phytochemistry. 67(22):2483-2493.

Thu VK, Thang NV, Nhiem NX, Tai BH, Nam NH, Kiem PV, Minh CV, Anh HLT, Kim N, Park S et al. 2015. Oleanane-type saponins from Glochidion glomerulatum and their cytotoxic activities. Phytochemistry. 116:213-220.

Trang DT, Huyen LT, Hang DTT, Nhiem NX, Yen PH, Tai BH, Anh HLT, Minh CV, Kiem PV. 2016. Biflavones and megastigmane glycosides from the leaves of Antidesma bunius. Vietnam Journal of Chemistry 54:434-438.

Yang D-S, Peng W-B, Yang Y-P, Liu K-C, Li X-L, Xiao W-L. 2015. Cytotoxic prenylated flavonoids from Macaranga indica. Fitoterapia. 103:187-191.

Yoder BJ, Cao S, Norris A, Miller JS, Ratovoson F, Razafitsalama J, Andriantsiferana R, Rasamison VE, Kingston DG. 2007. Antiproliferative prenylated stilbenes and flavonoids from Macaranga alnifolia from the Madagascar rainforest. J Nat Prod. 70(3):342-346 
Table 1. Cytotoxic effects of compounds

\begin{tabular}{ccccc}
\hline Compounds & \multicolumn{4}{c}{ IC $_{\mathbf{5 0}}(\boldsymbol{\mu M})^{a)}$} \\
\cline { 2 - 5 } & $\mathbf{K B}$ & MCF7 & HepG2 & LU \\
\hline $\mathbf{2}$ & $10.6 \pm 1.1$ & $15.7 \pm 1.2$ & $11.2 \pm 1.0$ & $19.0 \pm 1.3$ \\
$\mathbf{5}$ & $31.8 \pm 2.1$ & $38.7 \pm 2.8$ & $38.0 \pm 2.5$ & $37.5 \pm 2.9$ \\
$\mathbf{6}$ & $4.7 \pm 0.3$ & $8.0 \pm 0.6$ & $11.0 \pm 1.2$ & $9.0 \pm 0.6$ \\
$\mathbf{7}$ & $28.7 \pm 2.6$ & $16.0 \pm 1.2$ & $14.3 \pm 1.2$ & $7.0 \pm 0.5$ \\
$\mathbf{M X}^{\boldsymbol{b})}$ & $7.8 \pm 0.7$ & $10.3 \pm 1.1$ & $8.2 \pm 0.6$ & $7.7 \pm 0.4$ \\
\hline
\end{tabular}

Compounds 1,3,4, and 8-14 did not showed cytotoxic activity $\left(\mathrm{IC}_{50}>100 \mu \mathrm{M}\right)$

a) The concentration that inhibits $50 \%$ of cell growth was calculated $\left(\mathrm{IC}_{50}\right)$. Compounds were tested at a maximum concentration of $100 \mu \mathrm{M}$. Data are means of three experiments.

${ }^{b)}$ Mitoxantrone (MX), an anticancer agent, was used as reference compound. 
Figure 1. Chemical structures of compounds 1-14.<smiles></smiles><smiles>CC(C)=CCc1c(O)cc2oc(-c3ccc4c(c3)[C@@H](O)[C@@H](C(C)(C)O)O4)c(O)c(=O)c2c1O</smiles><smiles>CC(C)=CCc1c(O)cc2oc(-c3ccc4c(c3)[C@@H](O)[C@H](O)C(C)(C)O4)c(O)c(=O)c2c1O</smiles><smiles>CC(C)=CCc1cc(-c2oc3cc4c(c(O)c3c(=O)c2O)CC(C(O)(F)F)O4)ccc1O</smiles><smiles>CC(C)=CCc1cc(-c2oc3c(CCC(C)C)c(O)cc(O)c3c(=O)c2O)ccc1O</smiles><smiles>C=CCCO</smiles><smiles>CC(=O)O[C@@H](C)/C=C/[C@]1(C)C(C)=CC(=O)CC1(C)C</smiles>

$11 \mathrm{R}=\mathrm{H}$

$12 \mathrm{R}=\mathrm{OH}$<smiles>Cc1cc(=O)c2c(O)cc(O)c(CO)c2o1</smiles><smiles>O=c1cc(-c2ccc(O)cc2)oc2cc(O)c(Cl)c(O)c12</smiles><smiles>CO[C@H](C)/C=C/[C@@]1(O)C(C)=CC(=O)CC1(C)C</smiles>

13<smiles>COC(C)/C=C/[C@]1(O)C(C)(C)C[C@@H](O)C1(C)C</smiles> 


\title{
SUPPLEMENTARY MATERIAL
}

\section{Prenylated flavonoids and other constituents from Macaranga indica}

\author{
Le Tran Nguyen $\mathrm{Vu}^{\mathrm{a}, \mathrm{c}}$, Luu The Anh ${ }^{\mathrm{b}}$, Nguyen Thi Cuc ${ }^{\mathrm{a}, \mathrm{c}}$, \\ Nguyen Xuan Nhiem ${ }^{\mathrm{a}, \mathrm{c}}$, Bui Huu Tai ${ }^{\mathrm{a}, \mathrm{c}}$, Phan Van Kiem ${ }^{\mathrm{a}, \mathrm{c}}$, Marc Litaudon $^{\mathrm{d}}$, \\ Tran Dang Thache, Chau Van Minha ${ }^{\mathrm{a}}$, Huong Doan Thi Maia, , ${ }^{*}$, and Pham Van Cuonga,c* \\ advanced Center for Bioorganic Chemistry, Institute of Marine Biochemistry (IMBC), Vietnam \\ Academy of Science and Technology (VAST), Cau Giay, Hanoi, Vietnam \\ ${ }^{b}$ Central Institute for Natural Resources and Environmental Studies, Vietnam National \\ University, Hanoi, 19 Le Thanh Tong, Hoan Kiem, Hanoi, Vietnam \\ ${ }^{c}$ Graduate University of Science and Technology, VAST, Cau Giay, Hanoi, Vietnam \\ 'Institut de Chimie des Substances Naturelles, CNRS-ICSN, UPR 2301,_Université Paris-Saclay, \\ 91198, Gif-sur-Yvette, France \\ eInstitute of Applied Science and Technology, University Industry Vinh, Vinh, Vietnam
}

\begin{abstract}
Four new prenylated flavonoids, macarindicins I-IV (1-4) together with ten known metabolisms, broussoflavonol F (5), vedelianin (6), schweinfurthin E (7), vitexin (8), 2"-rhamnosyl vitexin (9), isovitexin (10), (6R,7E,9R)-9-hydroxy-megastigman-4,7-dien-3-one-9-O- $\beta$-D-glucopyranoside (11), 6S,9R)-roseoside (12), (6S,9S)-roseoside (13), and bridelionoside B (14) were isolated from the leaves of Macaranga indica. Their structures were determined on the basis of extensive spectroscopic methods, including 1D-, 2D-NMR and MS data. All the isolated compounds were evaluated for their cytotoxic activities against four human cancer cell lines including KB, MCF-7, HepG-2, and LU. As the results, compound $\mathbf{6}$ significantly exhibited cytotoxic activity against all tested human cancer cell lines with $\mathrm{IC}_{50}$ values ranging from 4.7 to $11.0 \mu \mathrm{M}$. Compounds $\mathbf{2}, \mathbf{5}$, and 7 showed moderate cytotoxic activity with $\mathrm{IC}_{50}$ values ranging from 9.0 to $38.7 \mu \mathrm{M}$.
\end{abstract}

Keywords: Macaranga indica, macarindicin, cytotoxic 


\section{Content}

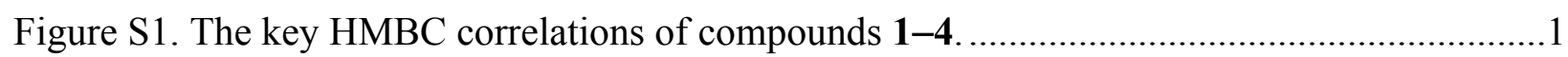

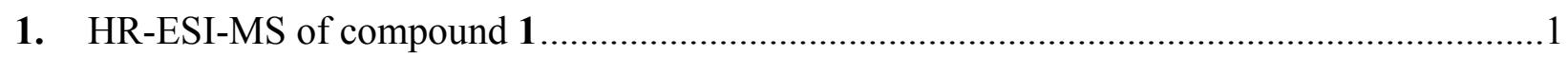

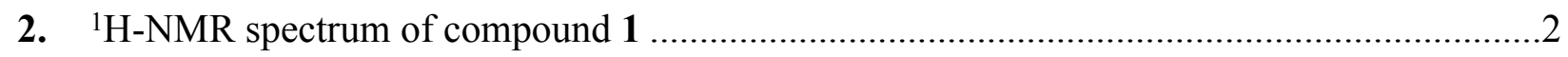

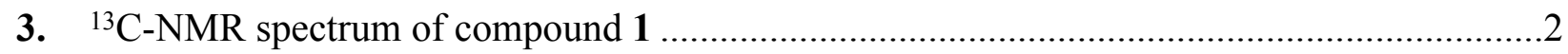

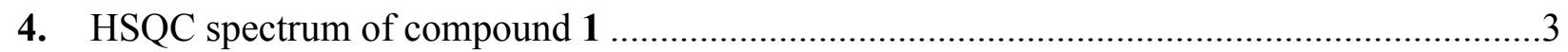

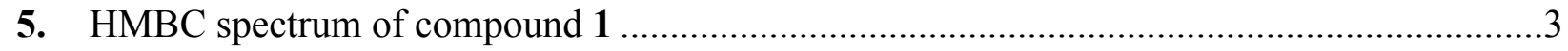

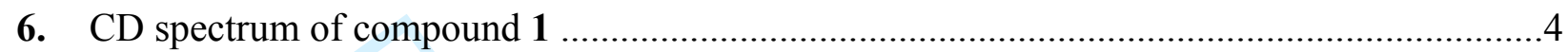

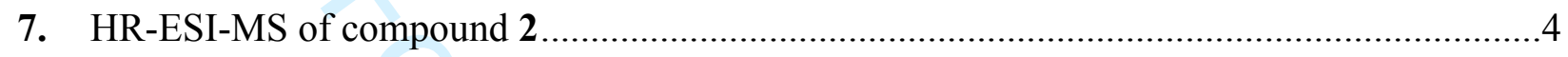

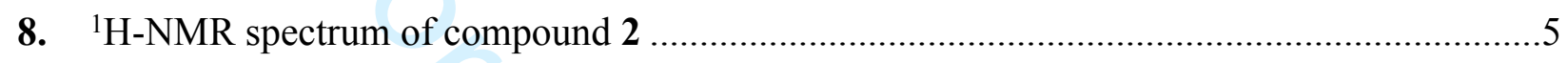

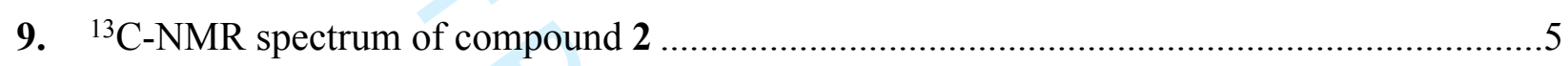

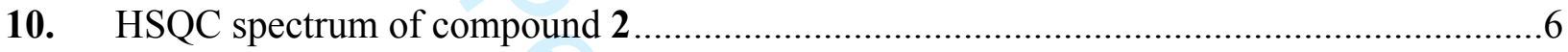

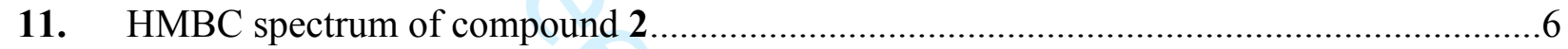

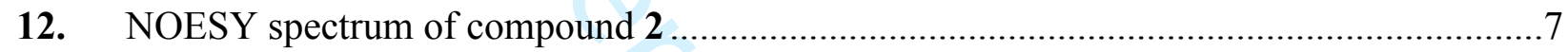

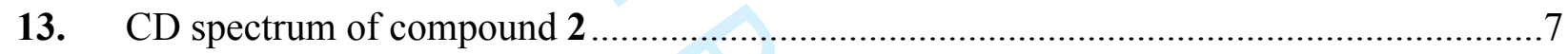

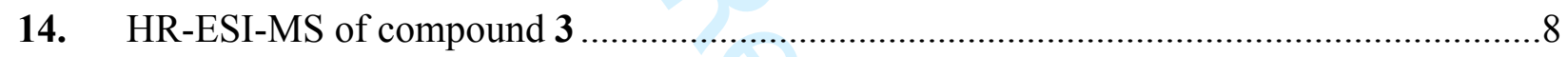

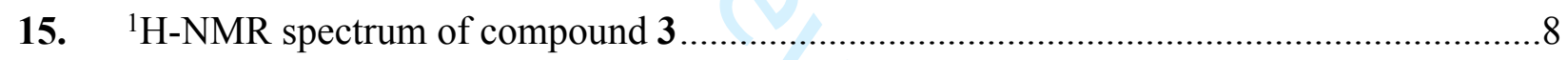

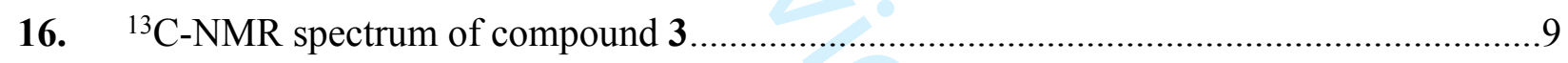

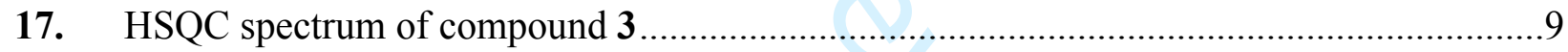

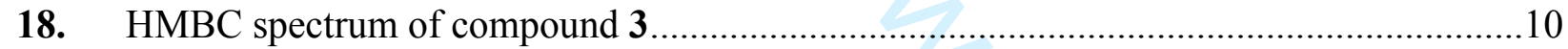

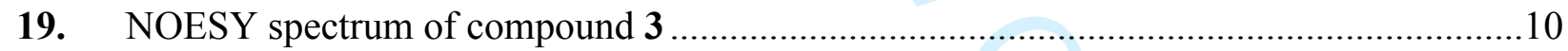

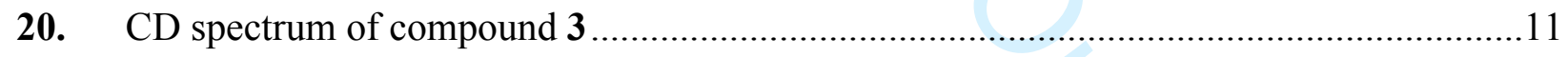

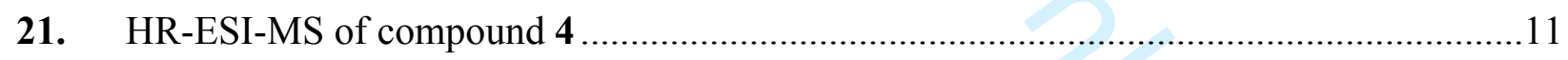

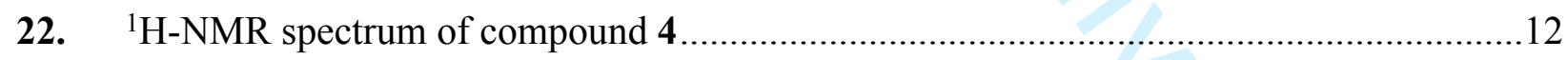

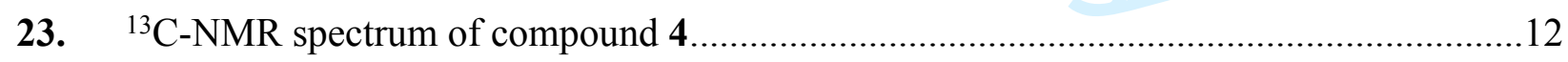

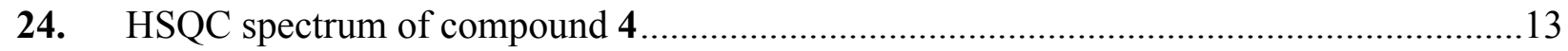

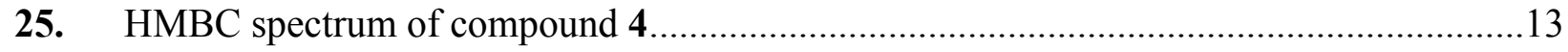

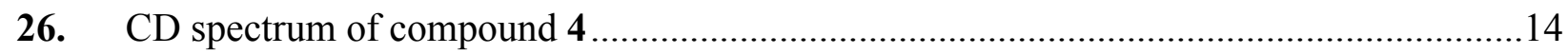


Figure S1. The key HMBC correlations of compounds 1-4.

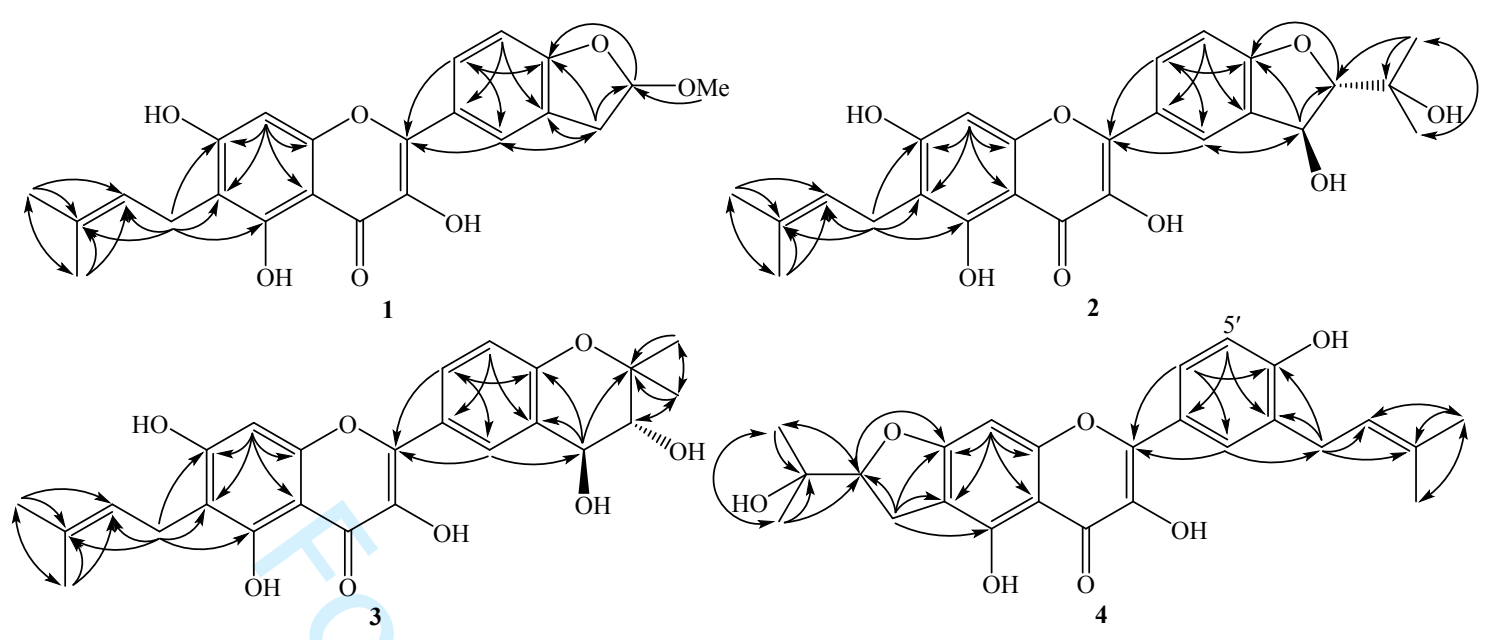

1. HR-ESI-MS of compound 1

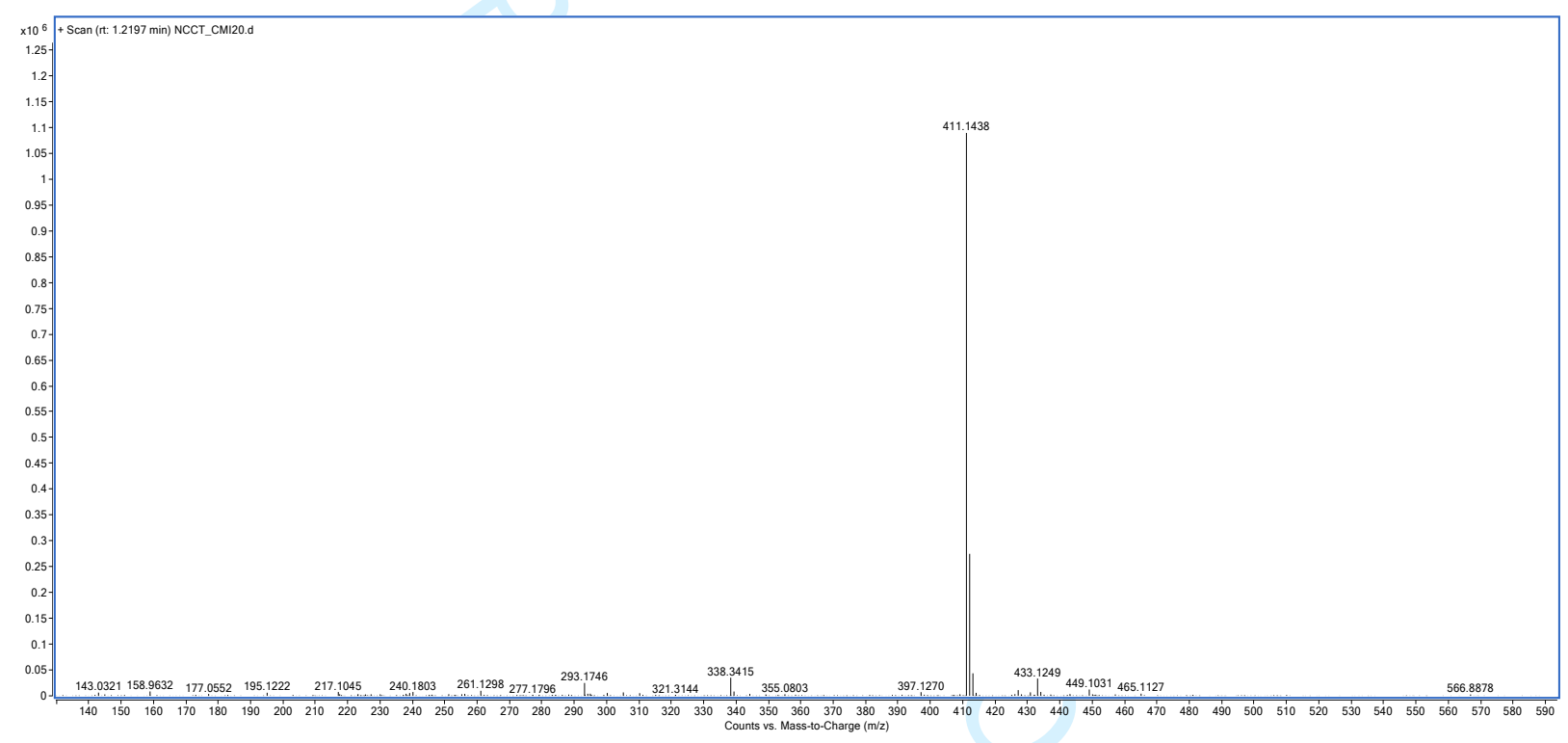


2. ${ }^{1} \mathrm{H}-\mathrm{NMR}$ spectrum of compound $\mathbf{1}$
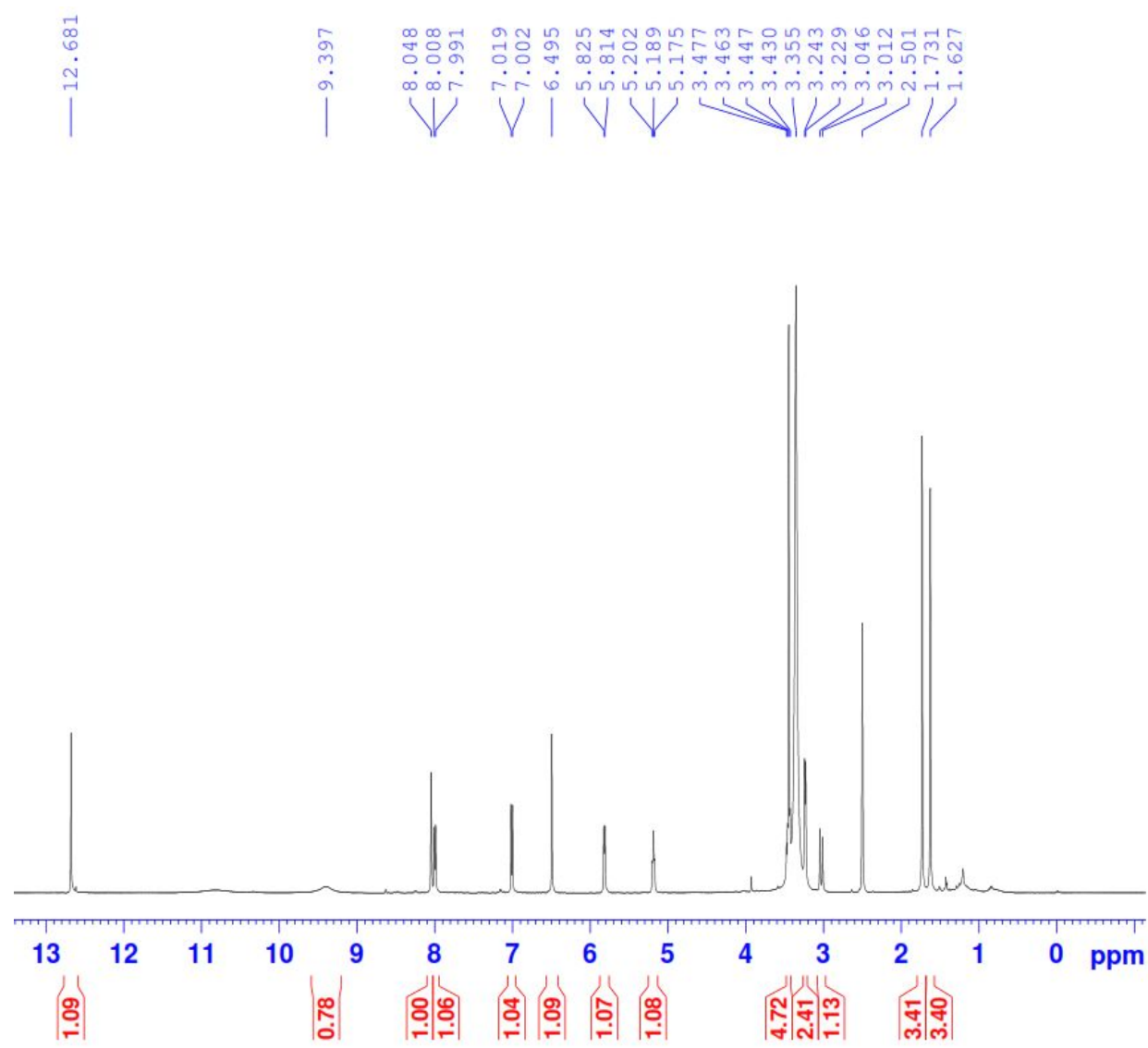

3. ${ }^{13} \mathrm{C}-\mathrm{NMR}$ spectrum of compound $\mathbf{1}$

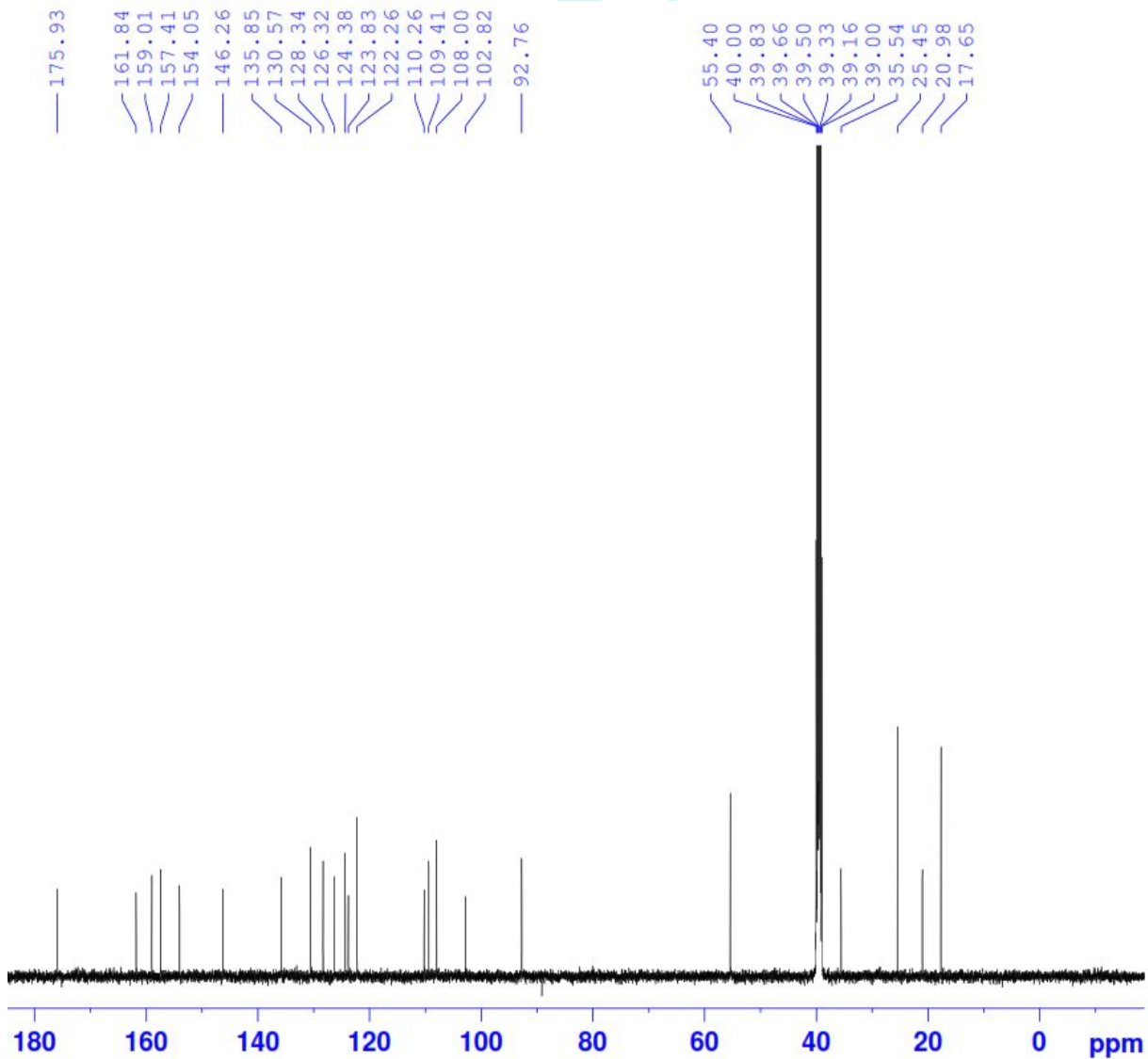


4. HSQC spectrum of compound $\mathbf{1}$

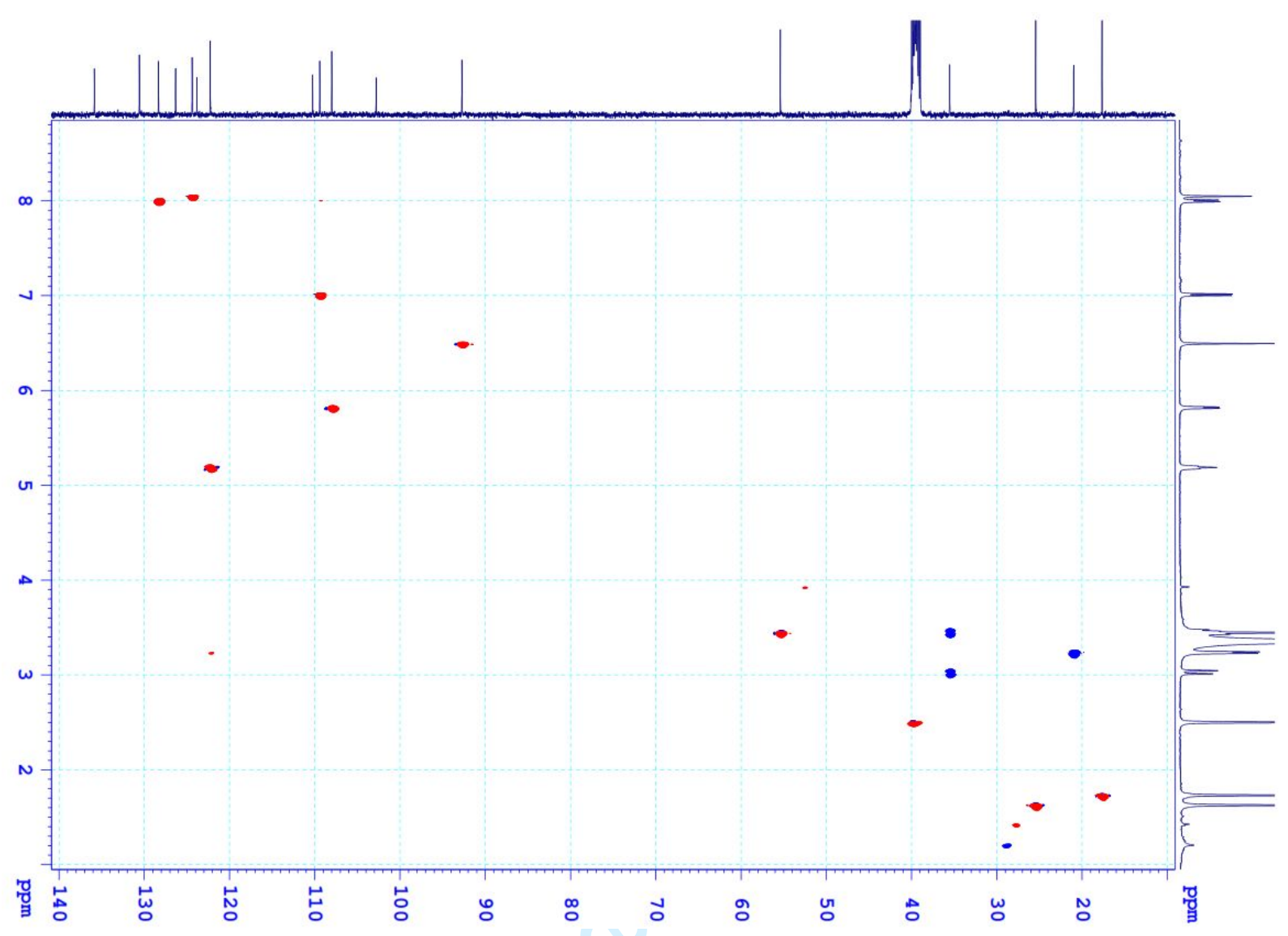

5. HMBC spectrum of compound 1

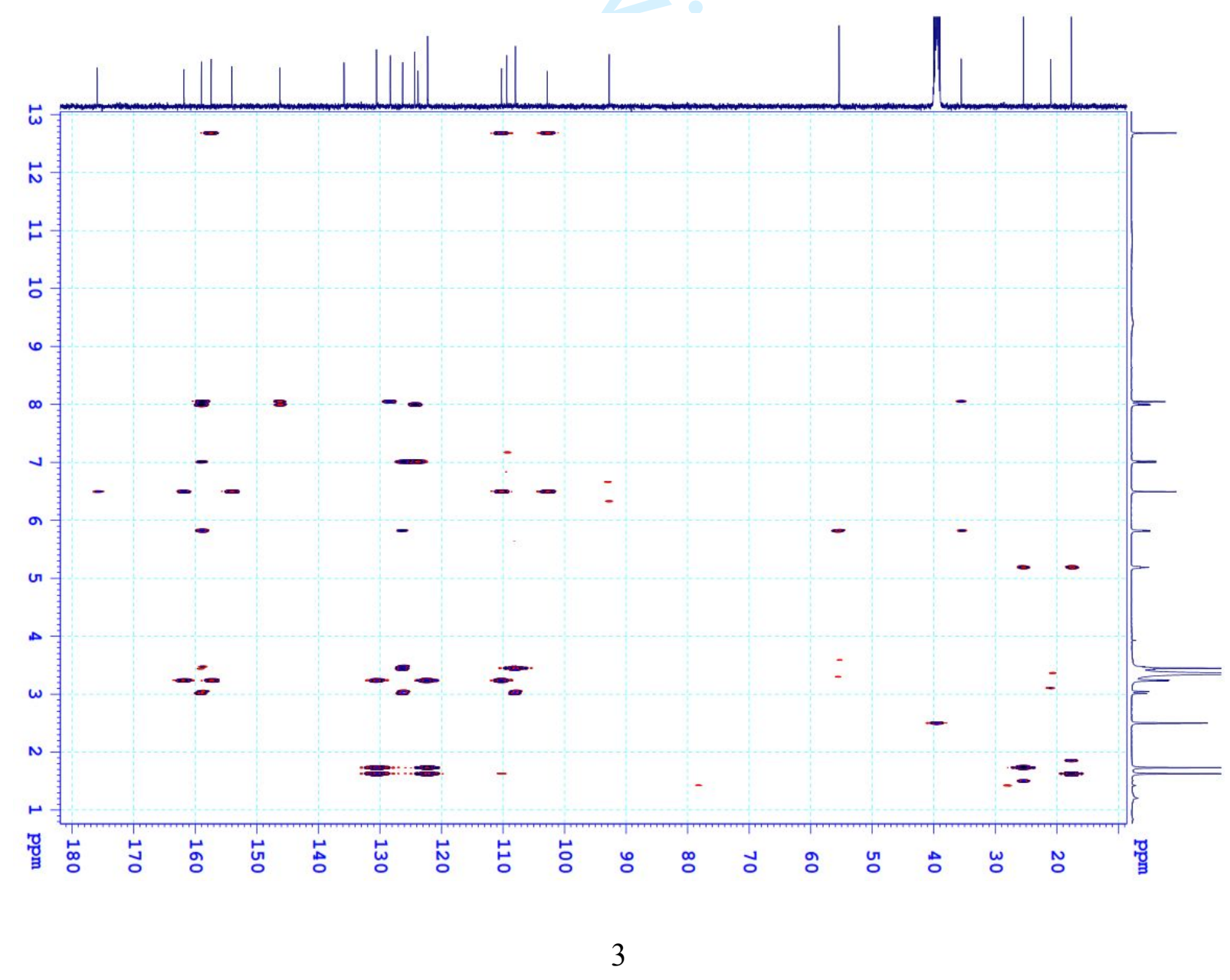


6. CD spectrum of compound $\mathbf{1}$

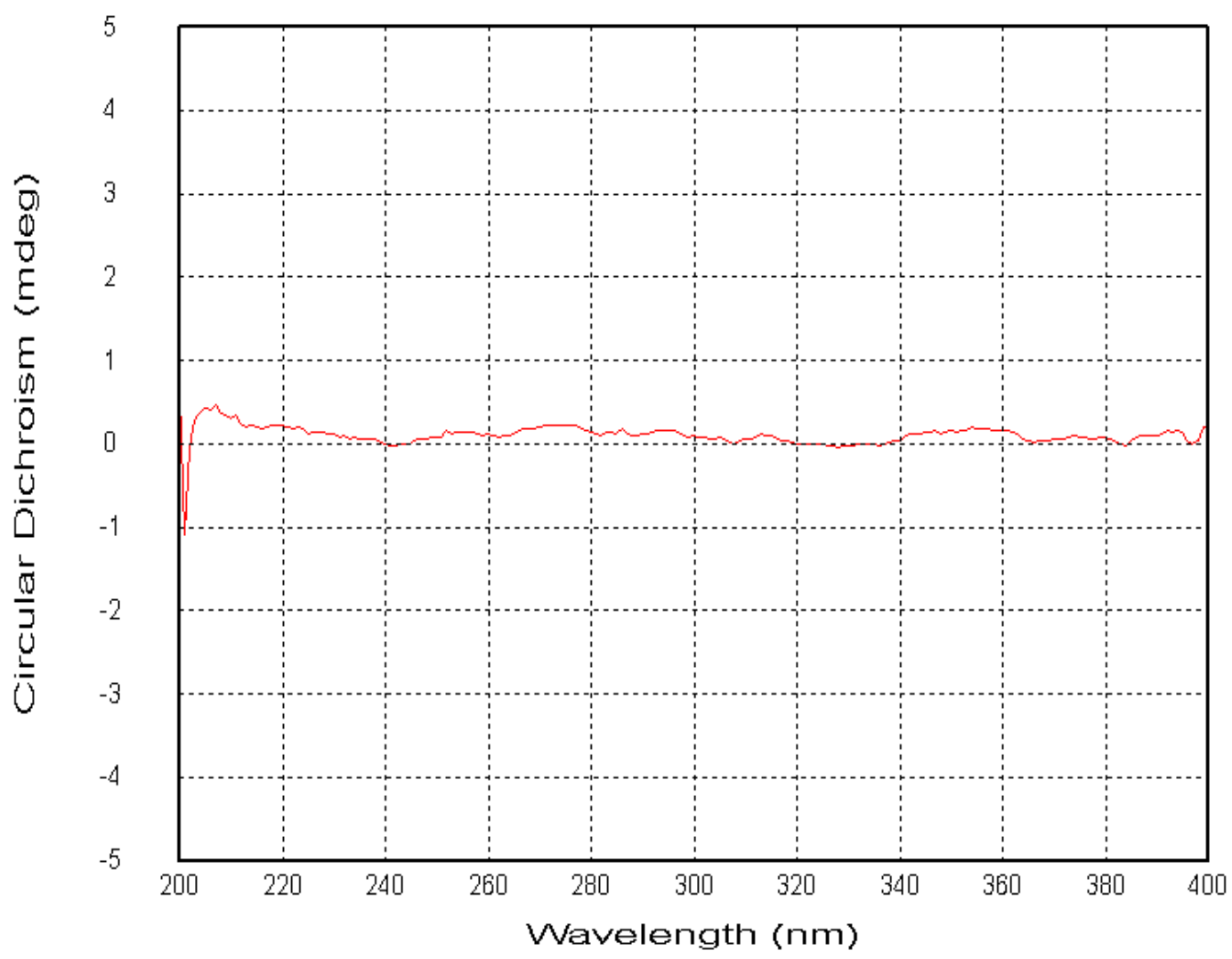

7. HR-ESI-MS of compound 2

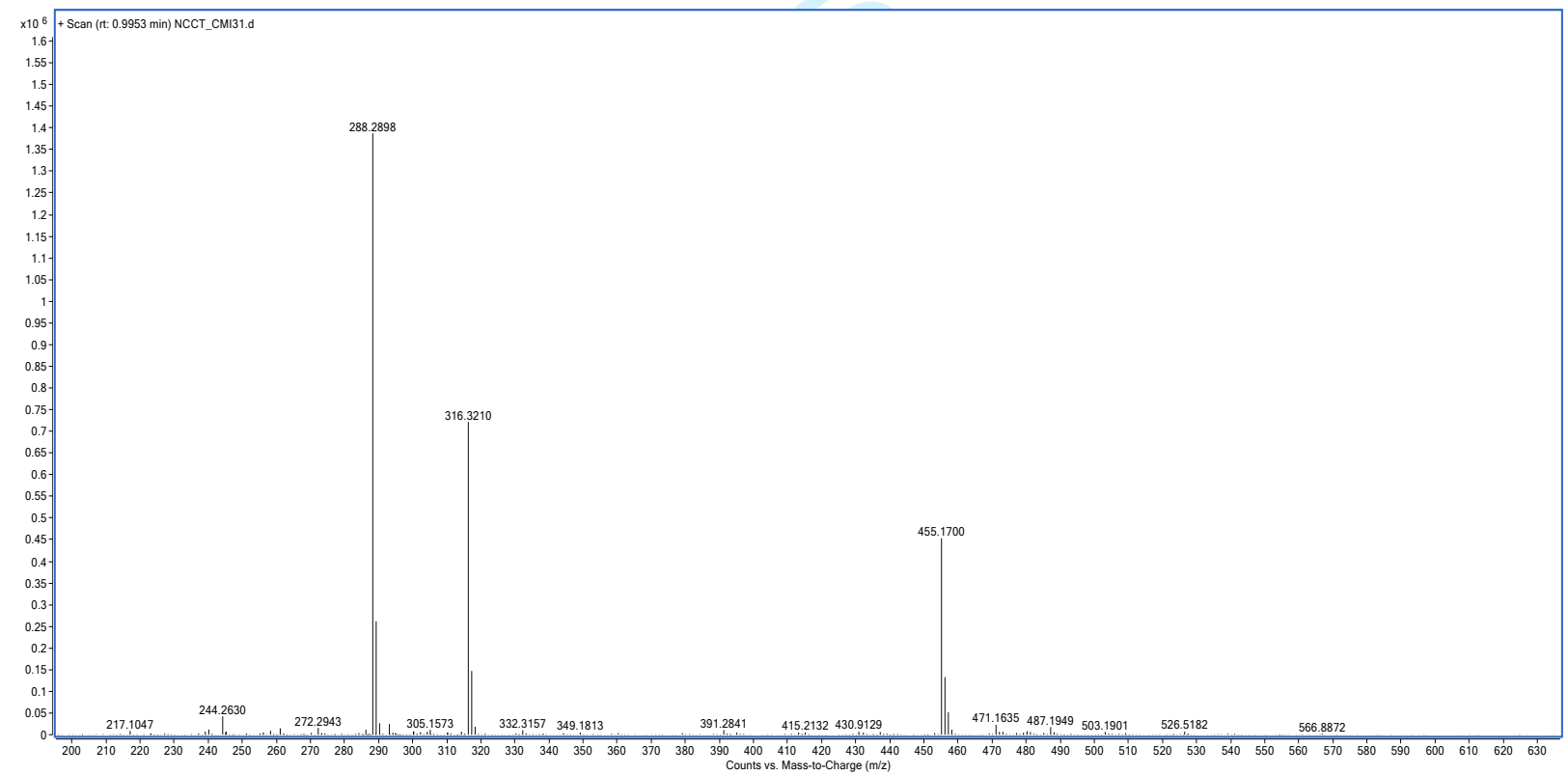


8. ${ }^{1} \mathrm{H}-\mathrm{NMR}$ spectrum of compound 2

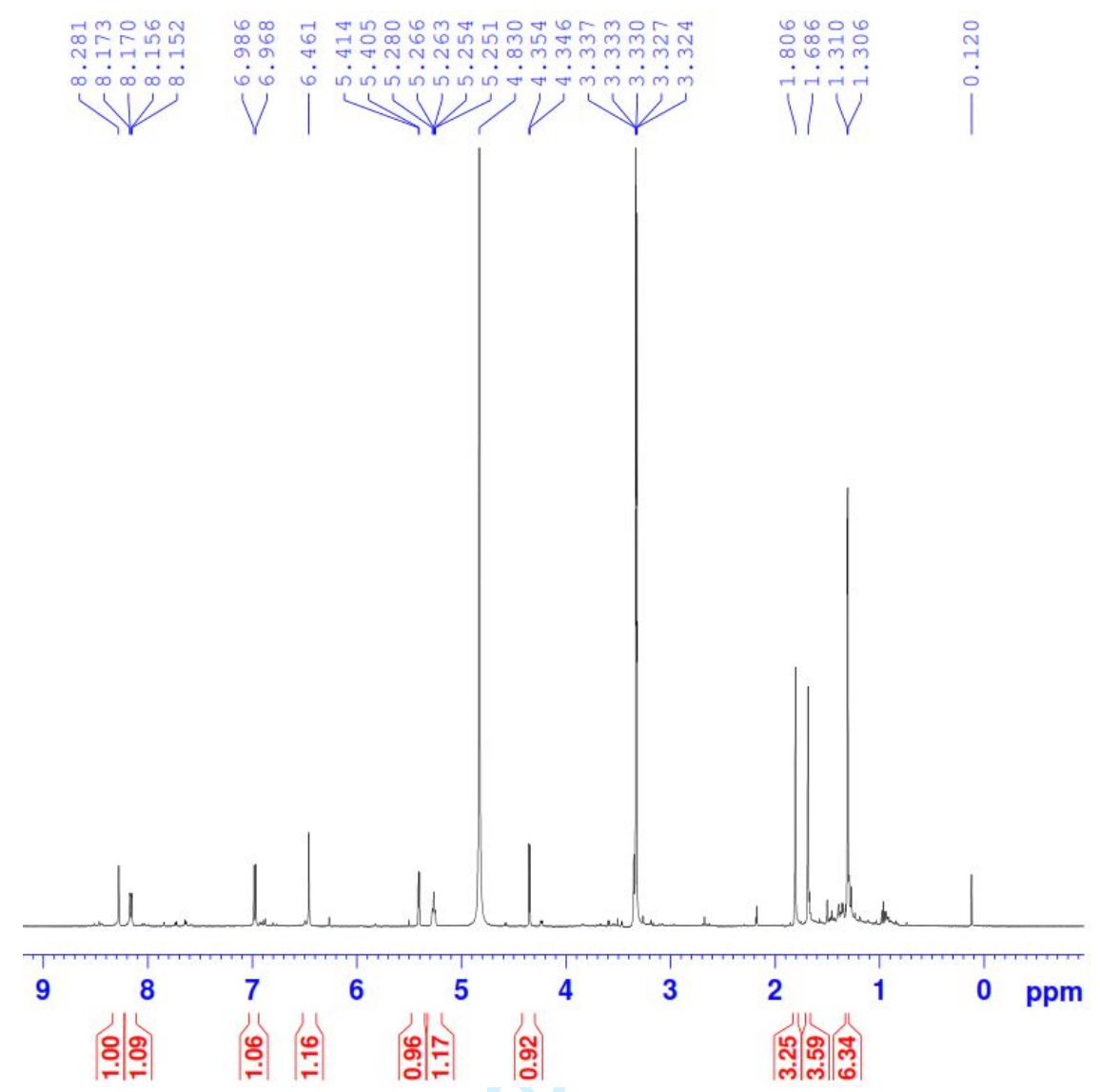

9. ${ }^{13} \mathrm{C}-\mathrm{NMR}$ spectrum of compound 2
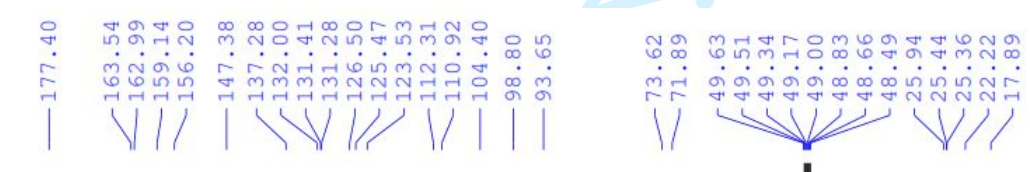

37

38

39

40

41

42

43

44

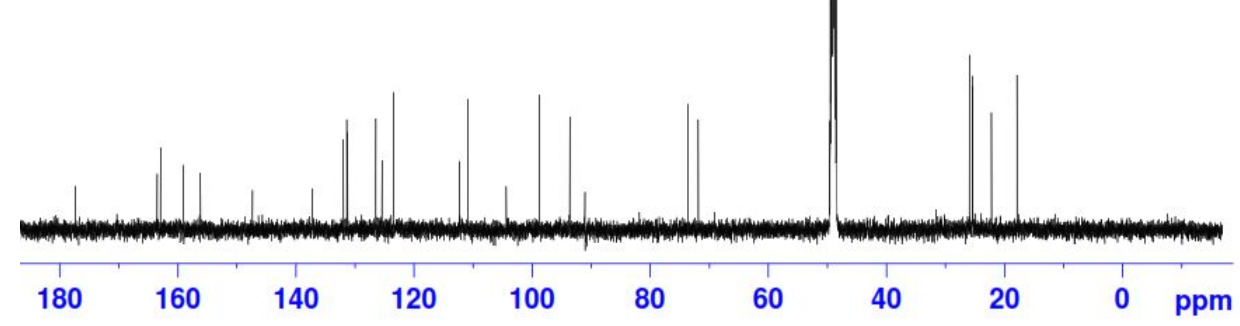


10. HSQC spectrum of compound 2

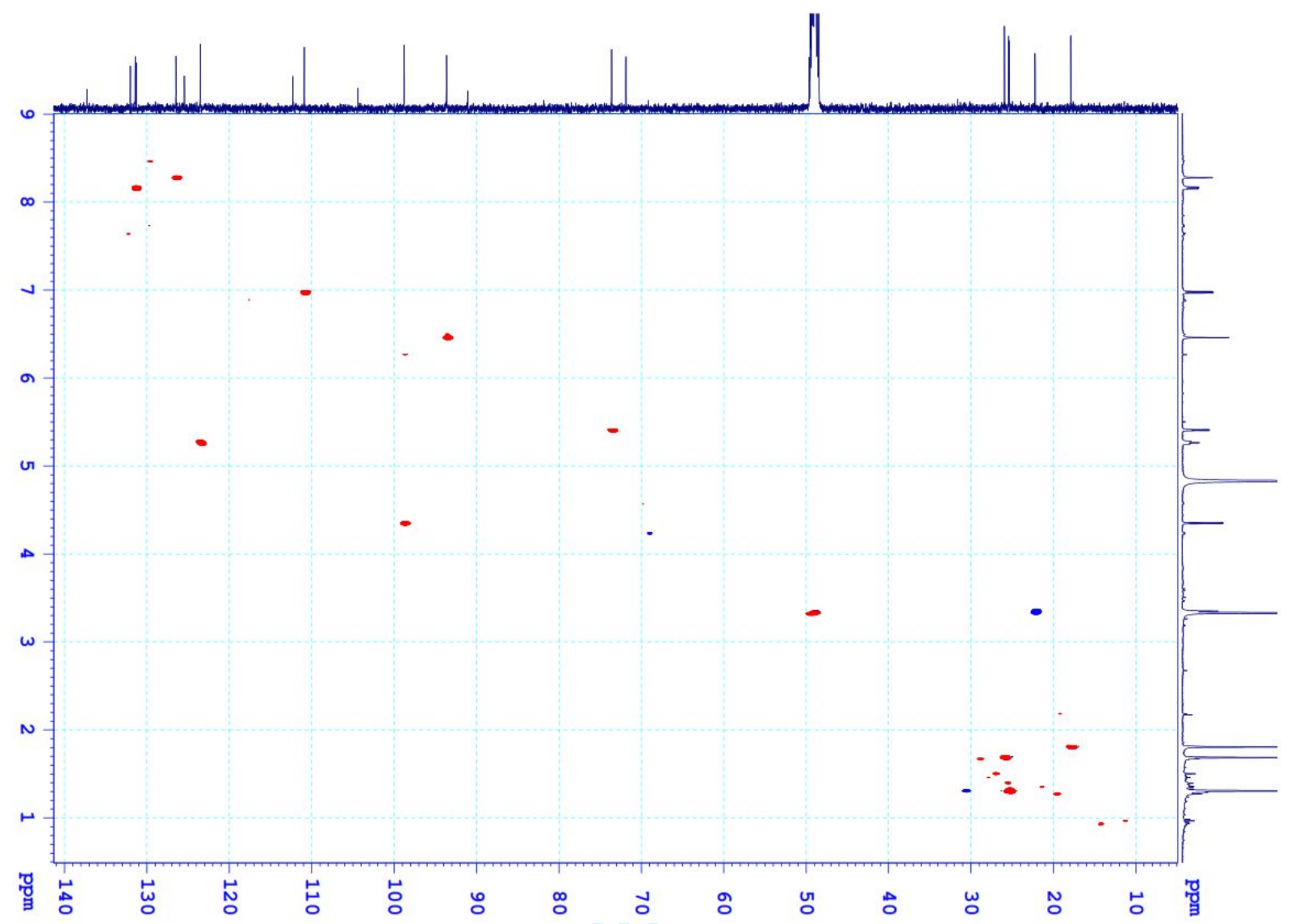

11. HMBC spectrum of compound 2

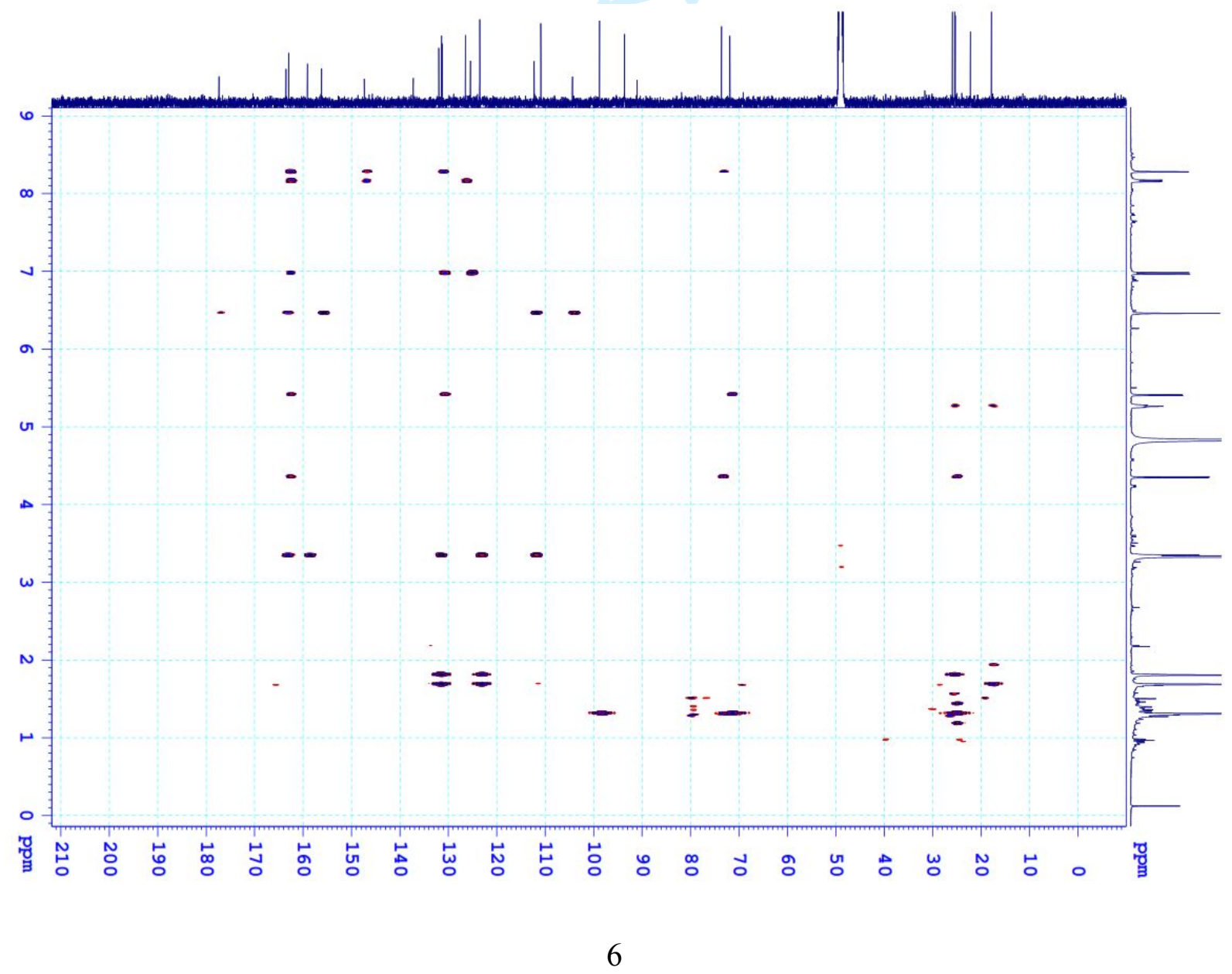


12. NOESY spectrum of compound 2

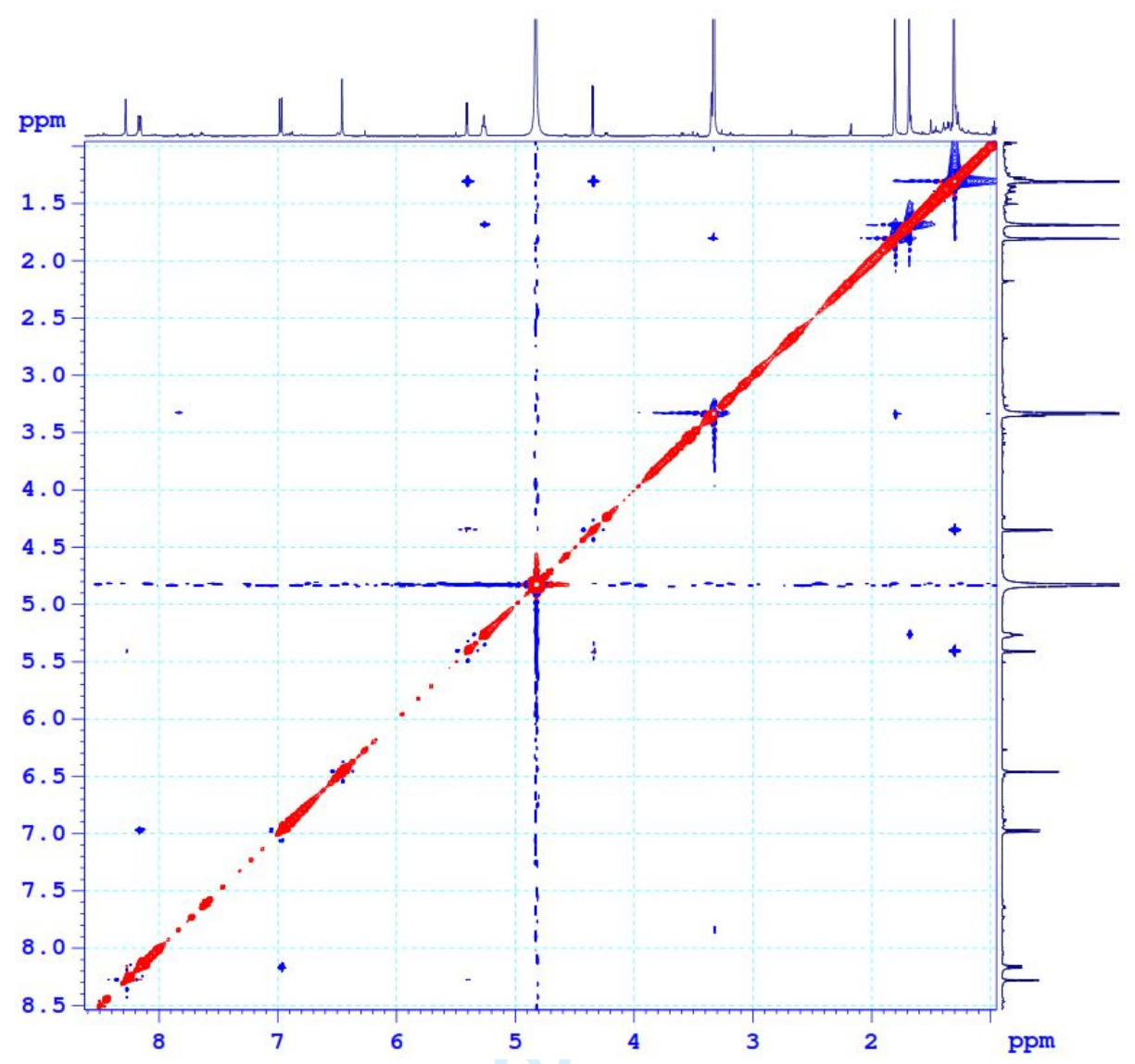

13. CD spectrum of compound 2

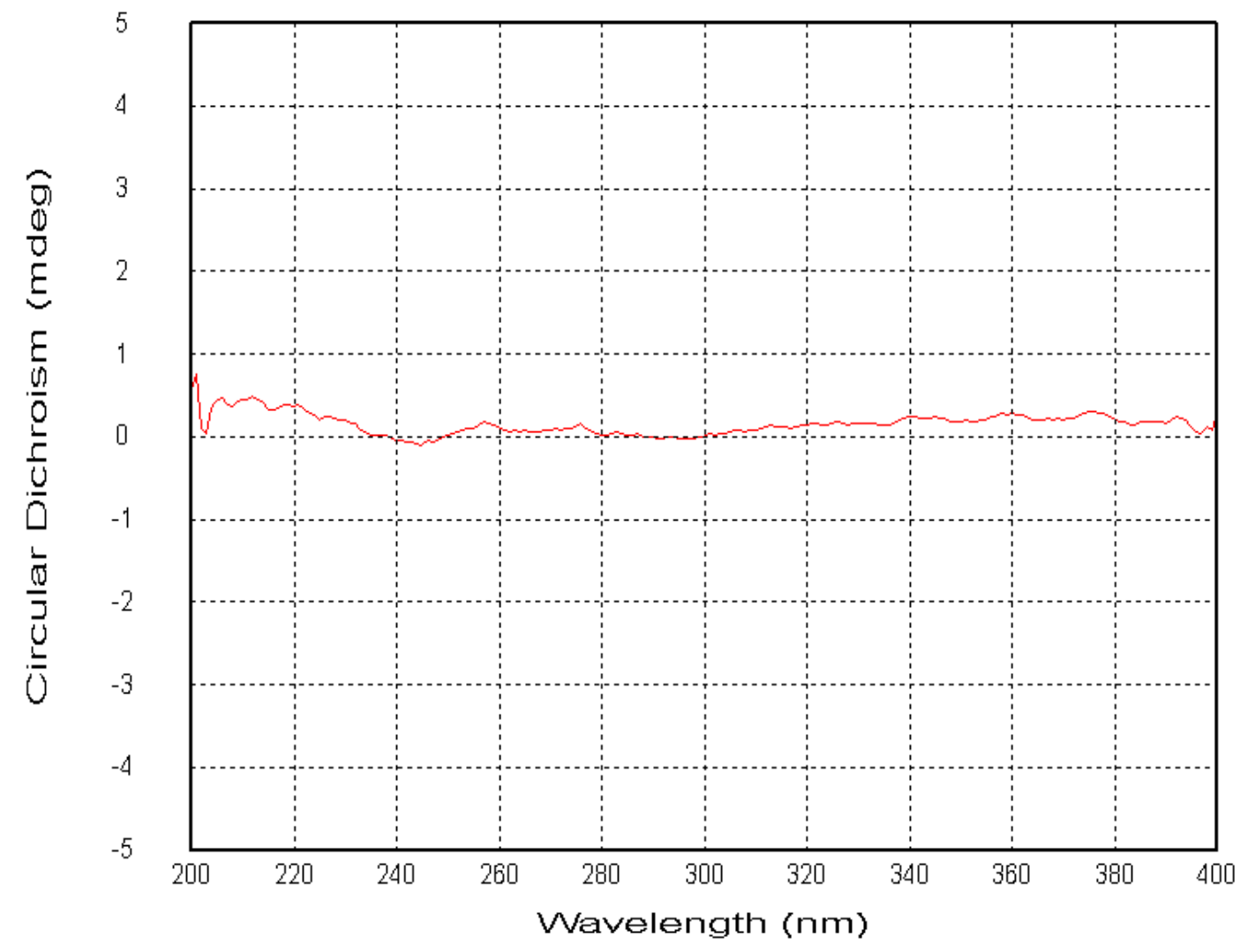


14. HR-ESI-MS of compound 3

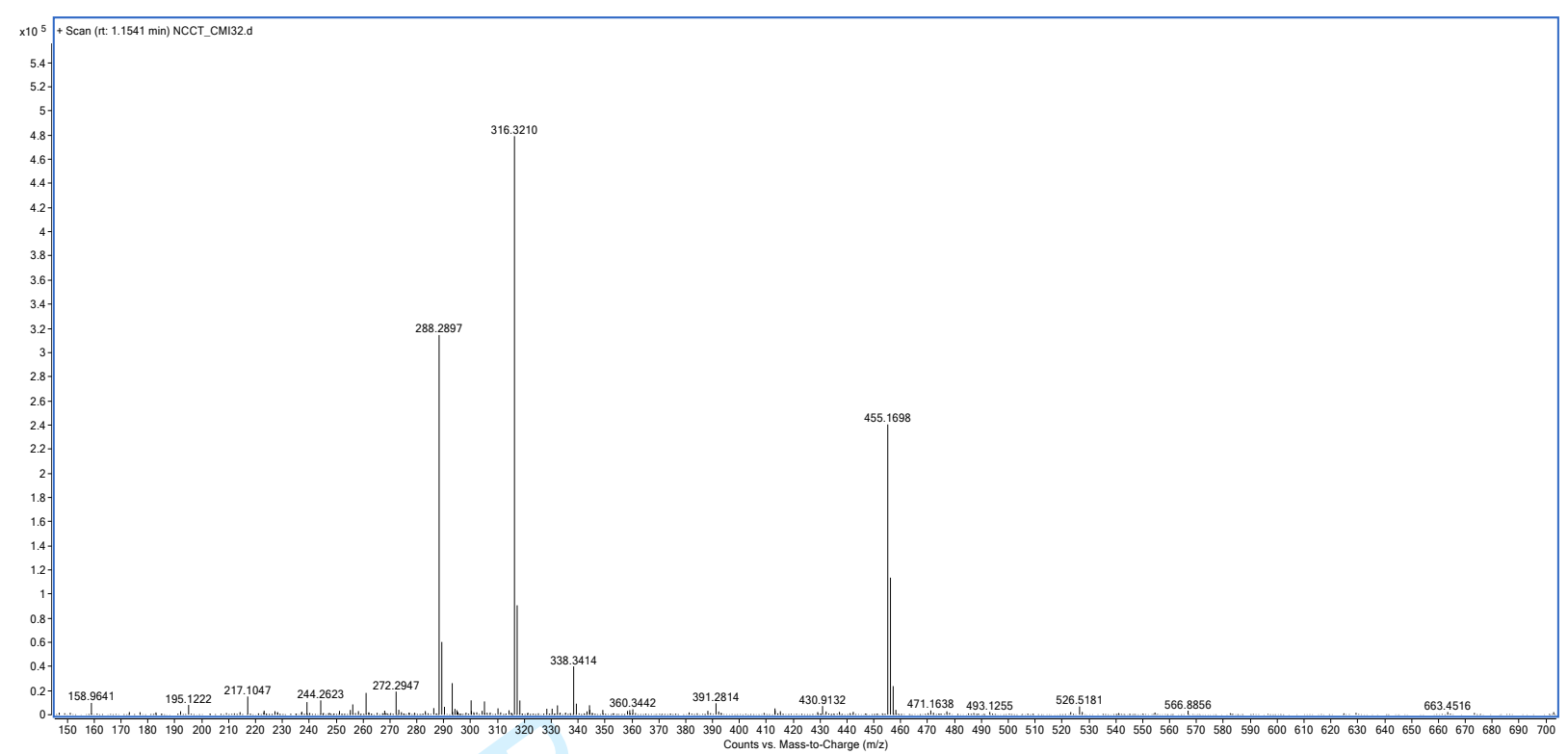

15. ${ }^{1} \mathrm{H}-\mathrm{NMR}$ spectrum of compound 3

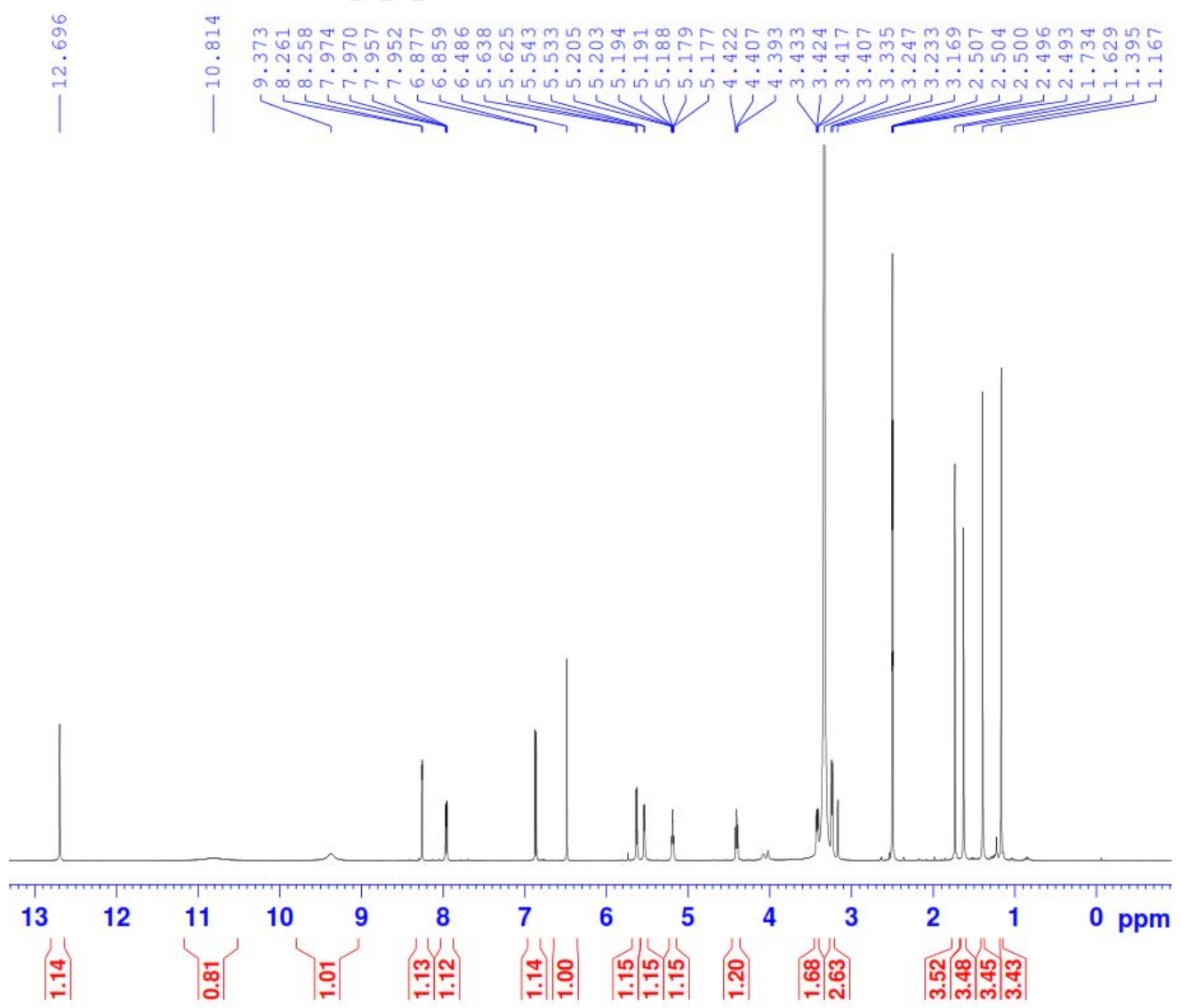


16. ${ }^{13} \mathrm{C}-\mathrm{NMR}$ spectrum of compound 3

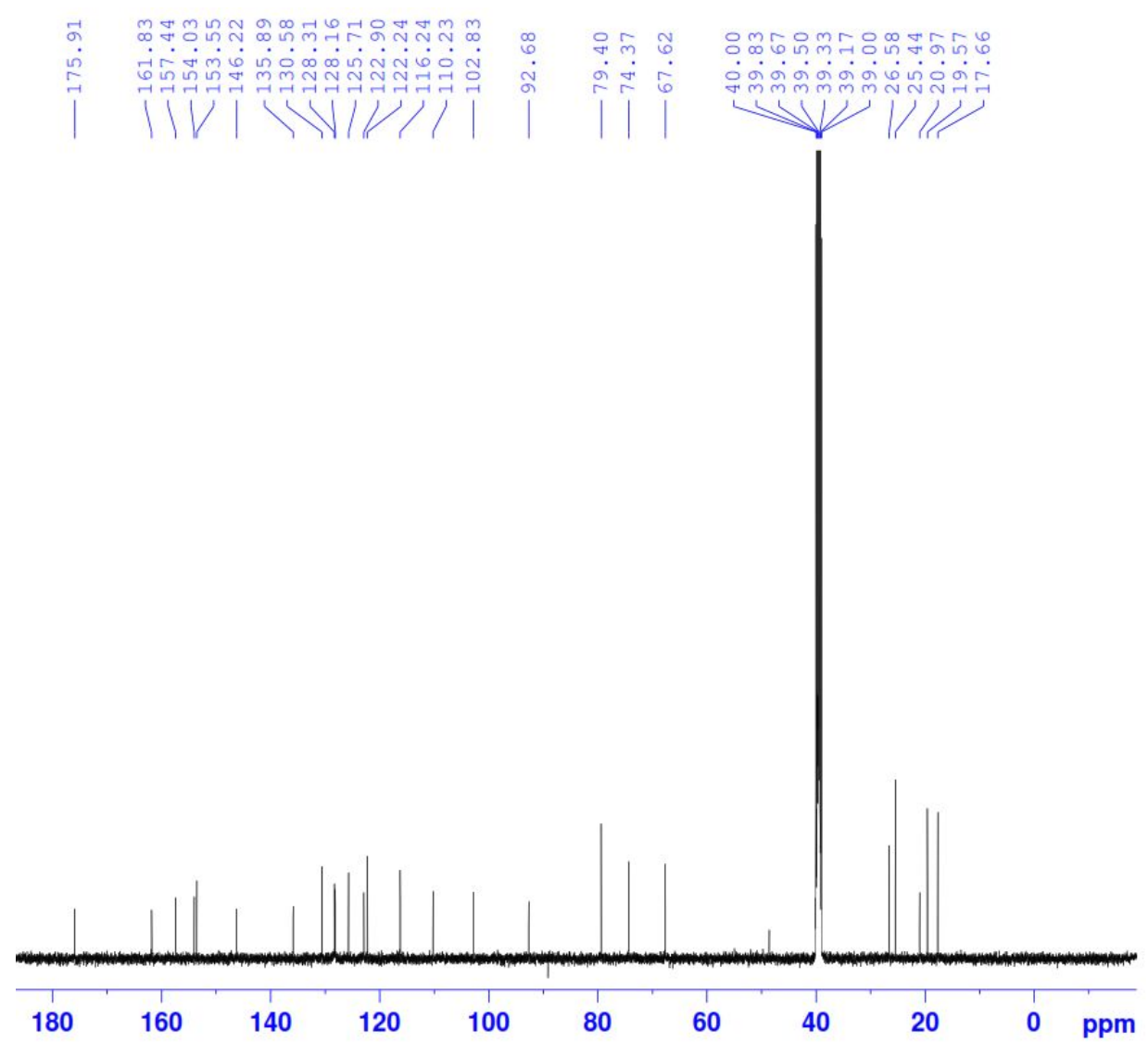

17. HSQC spectrum of compound 3

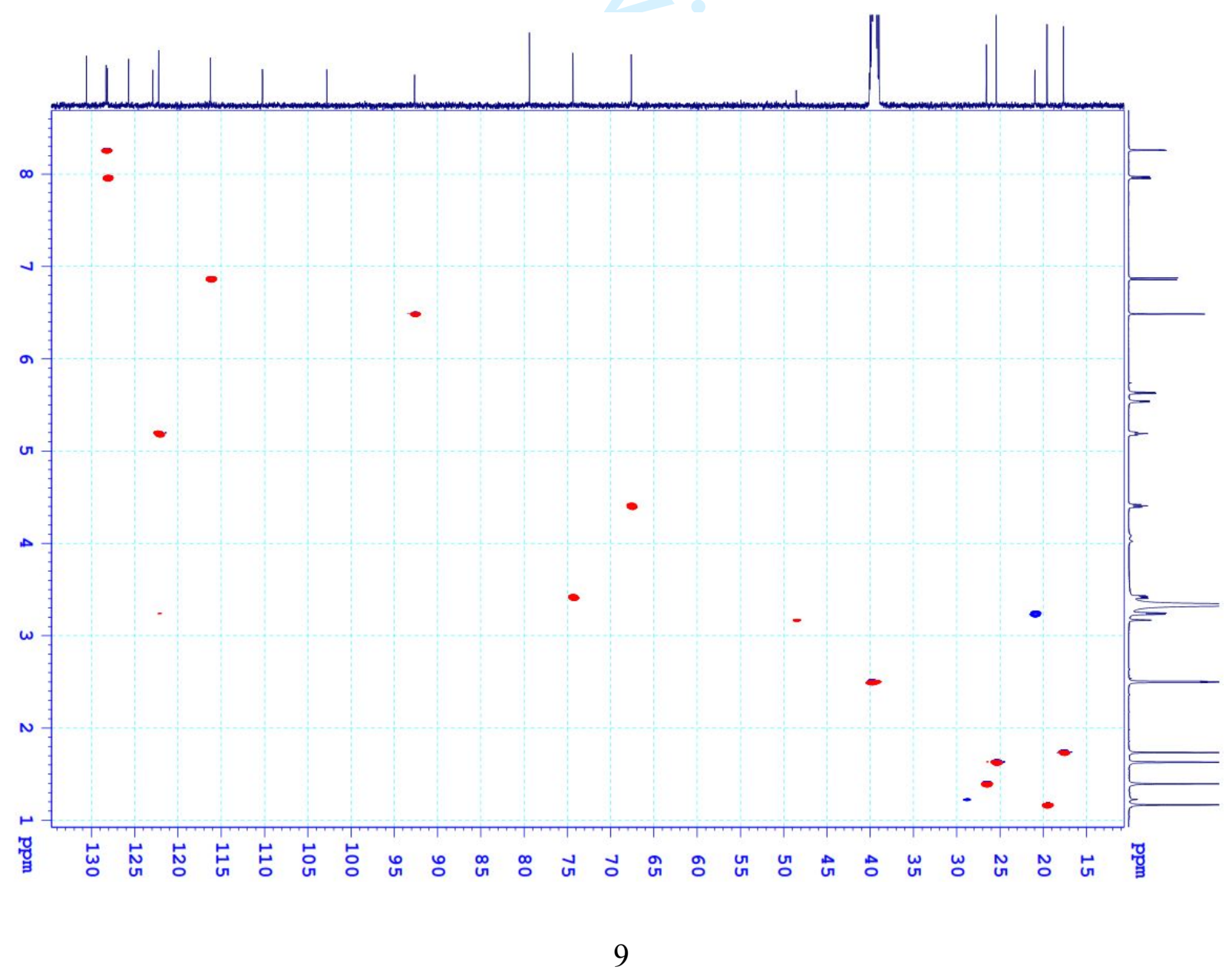


18. HMBC spectrum of compound 3

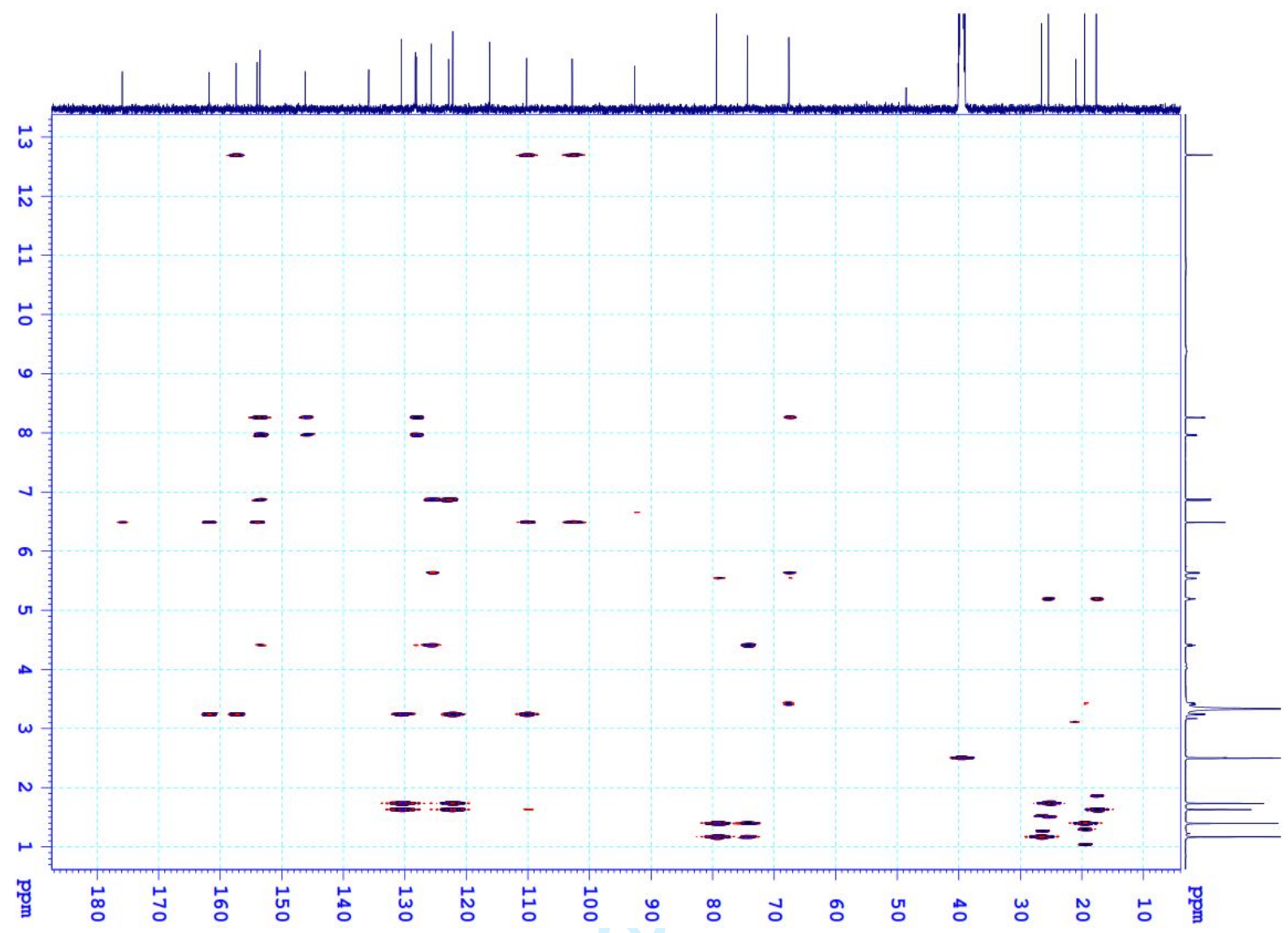

19. NOESY spectrum of compound 3

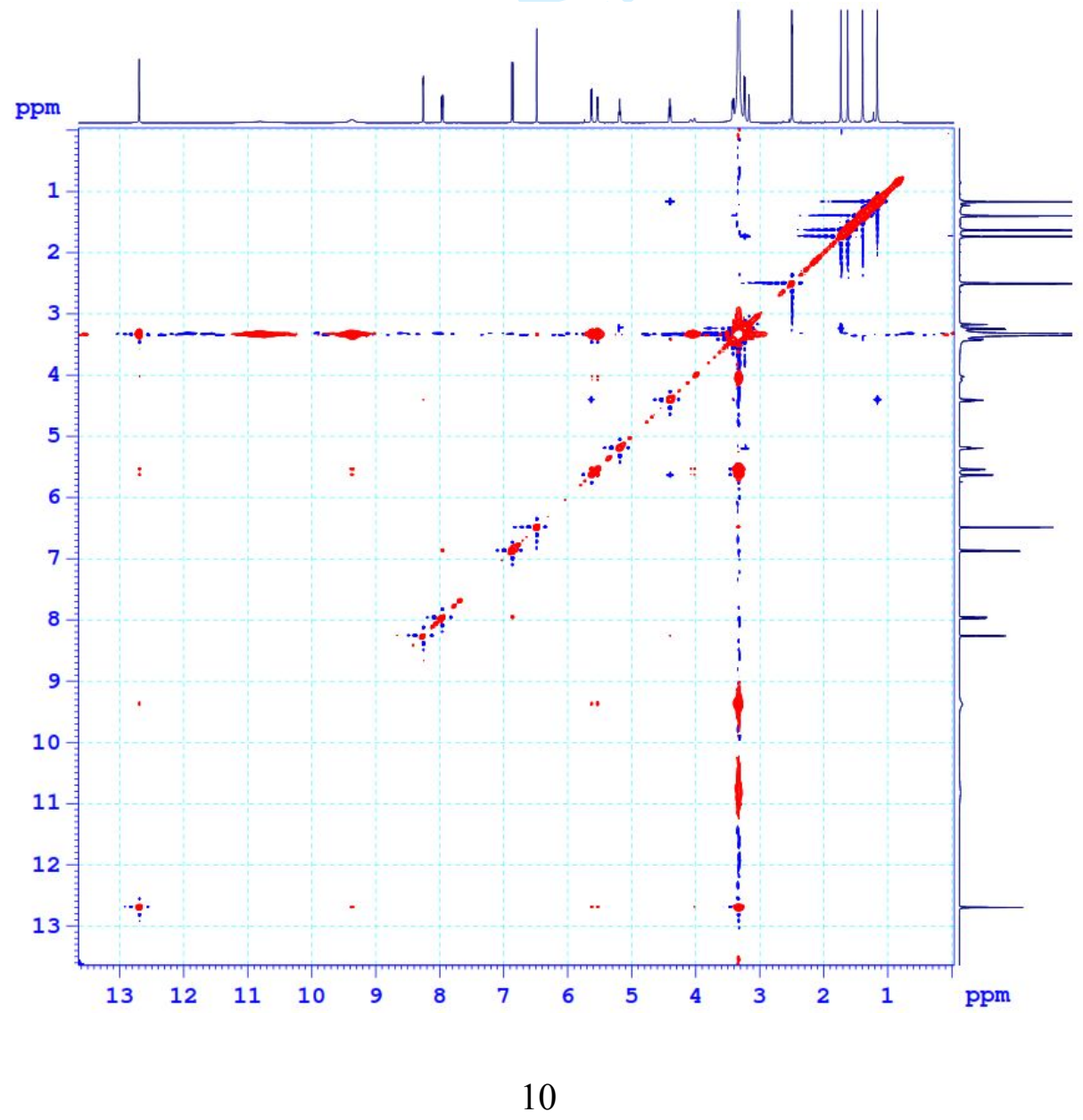

URL: http://mc.manuscriptcentral.com/gnpl 
20. CD spectrum of compound 3

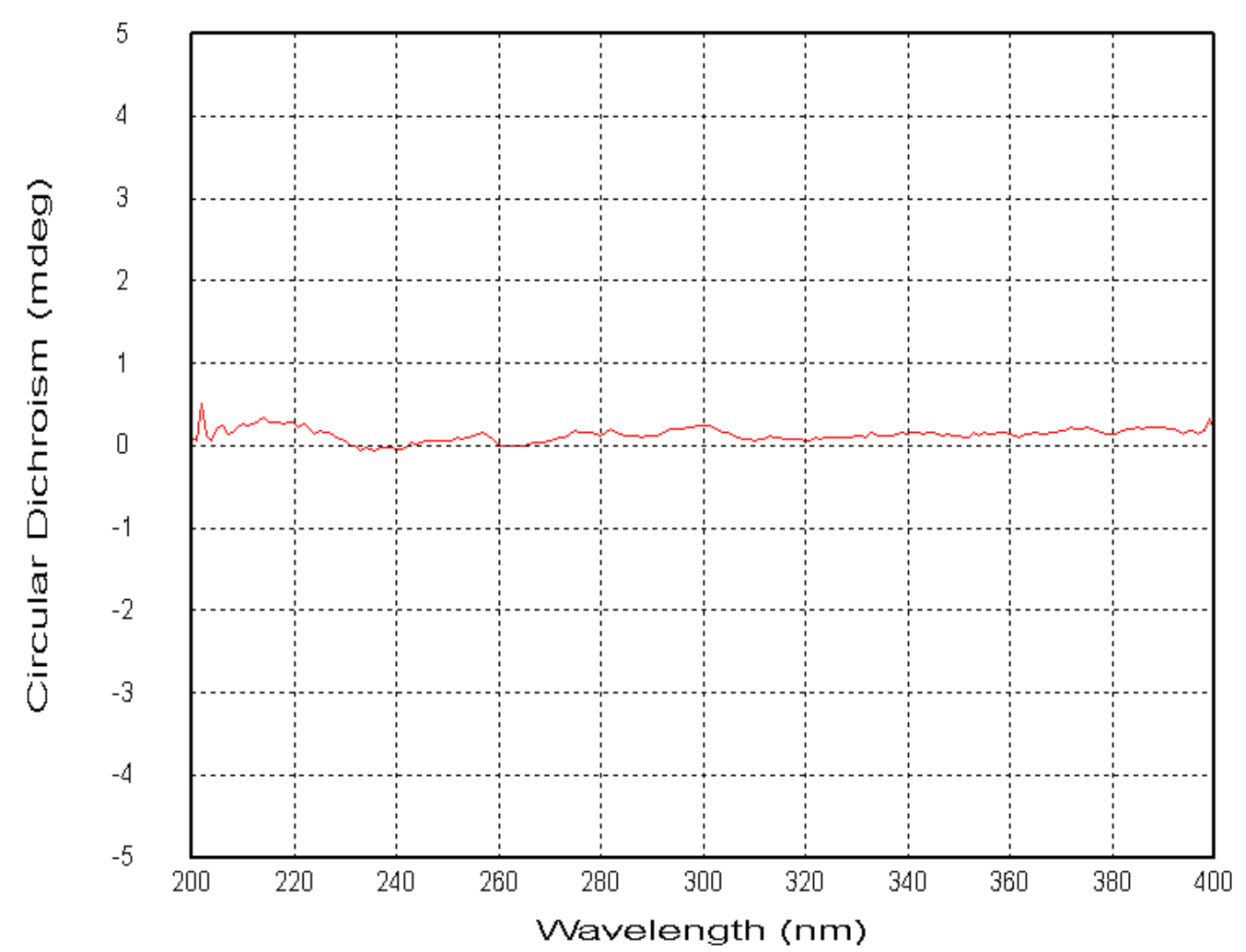

21. HR-ESI-MS of compound 4

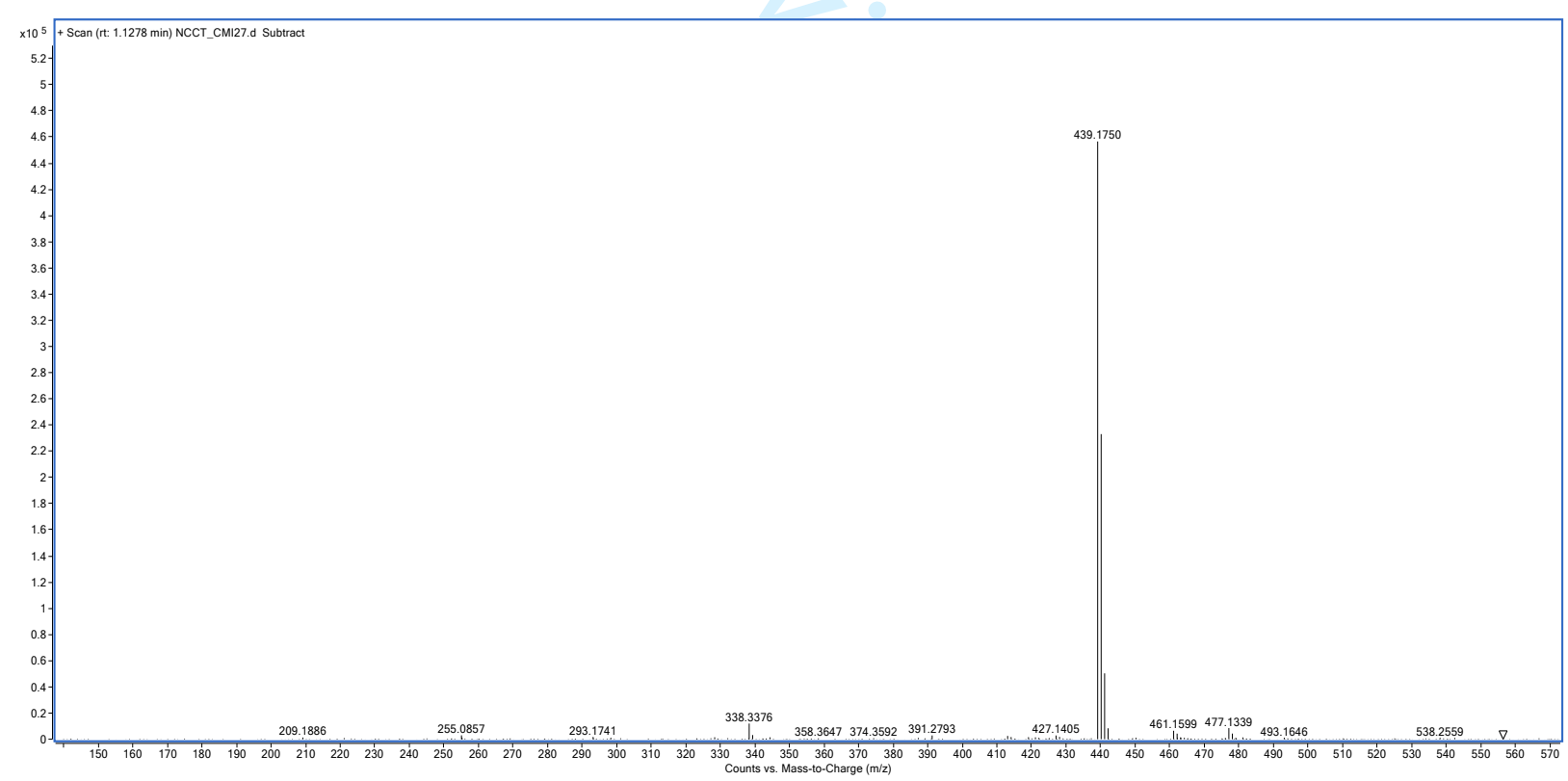


22. ${ }^{1} \mathrm{H}-\mathrm{NMR}$ spectrum of compound 4

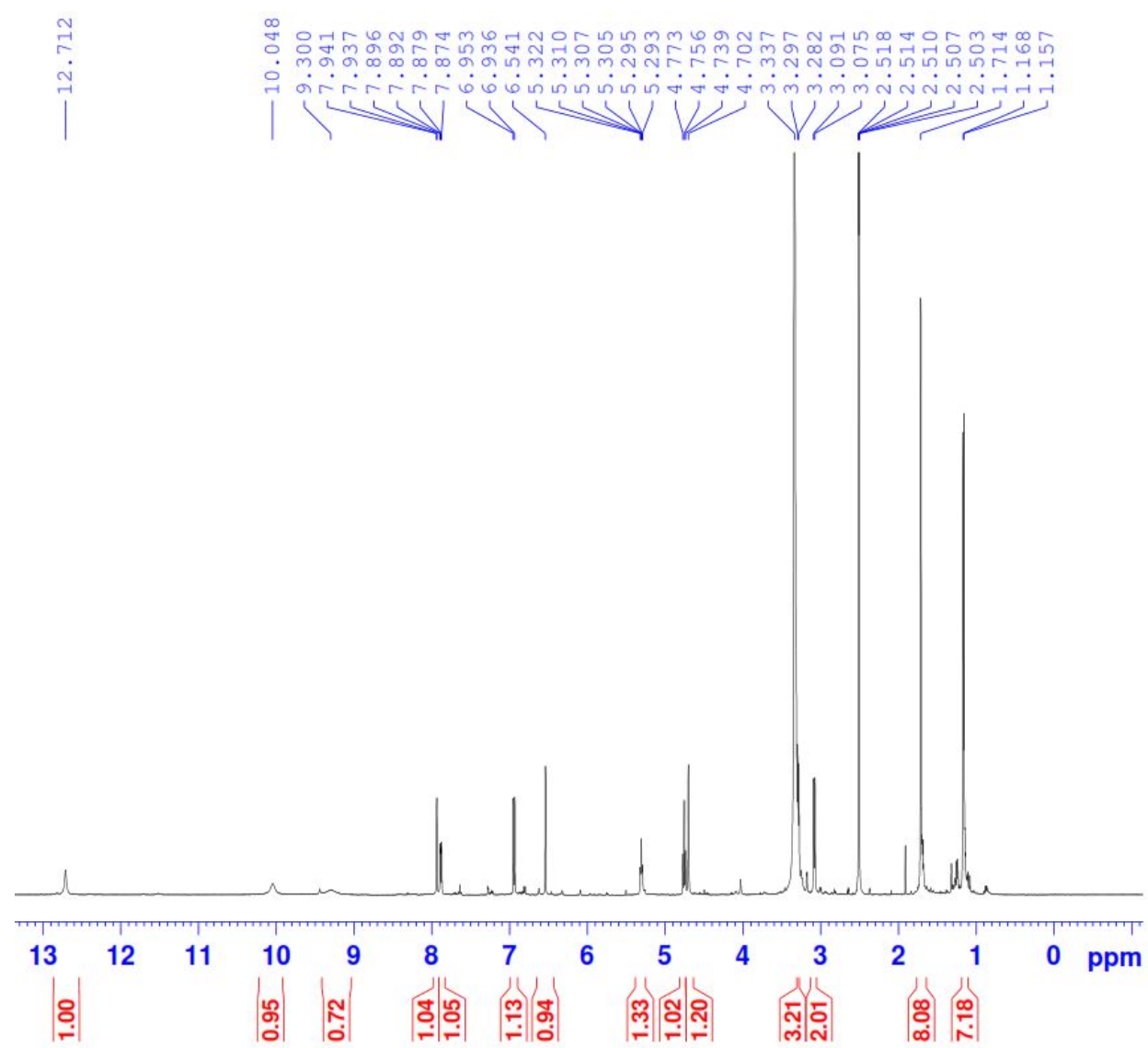

23. ${ }^{13} \mathrm{C}-\mathrm{NMR}$ spectrum of compound 4

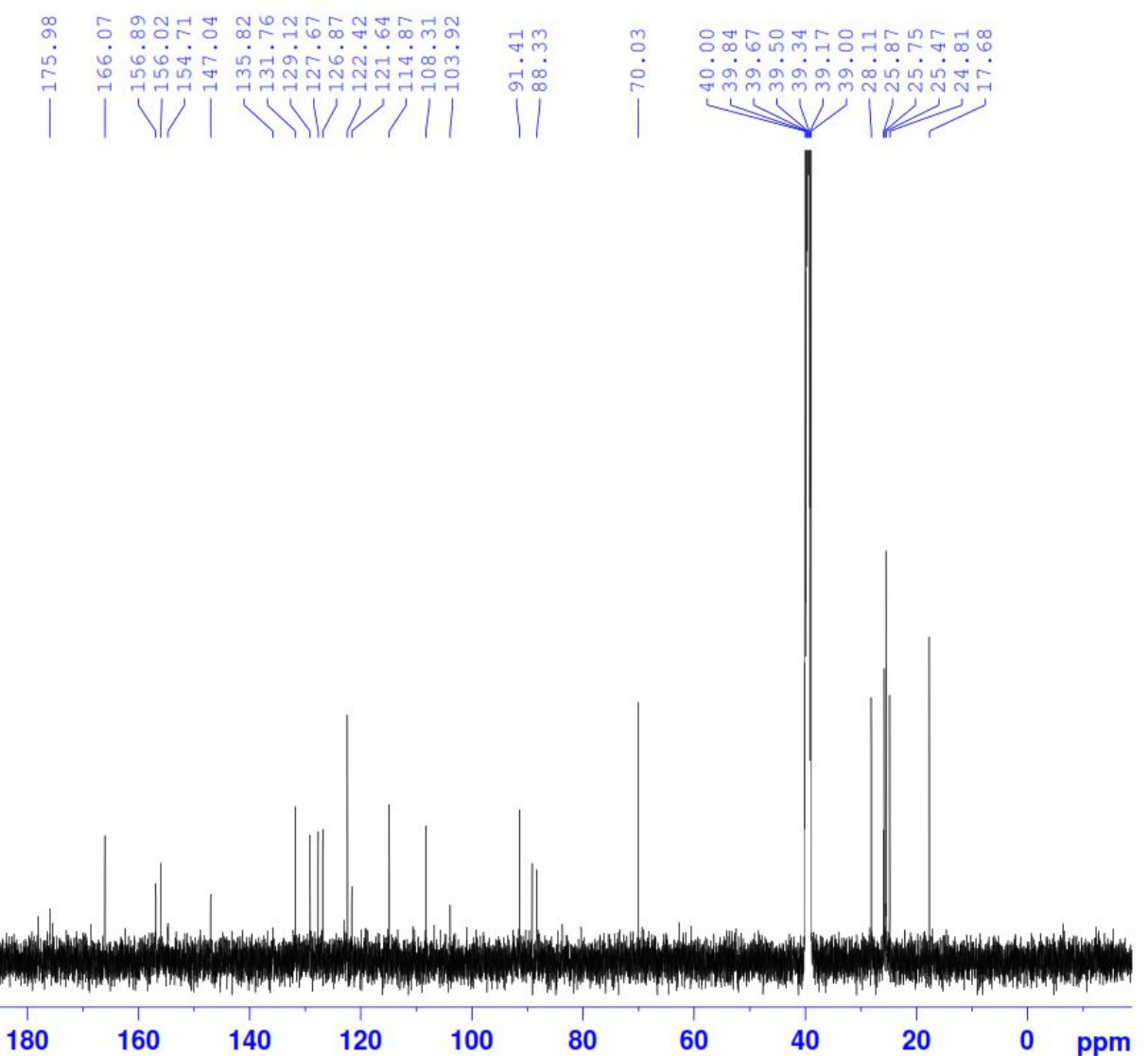


24. HSQC spectrum of compound 4

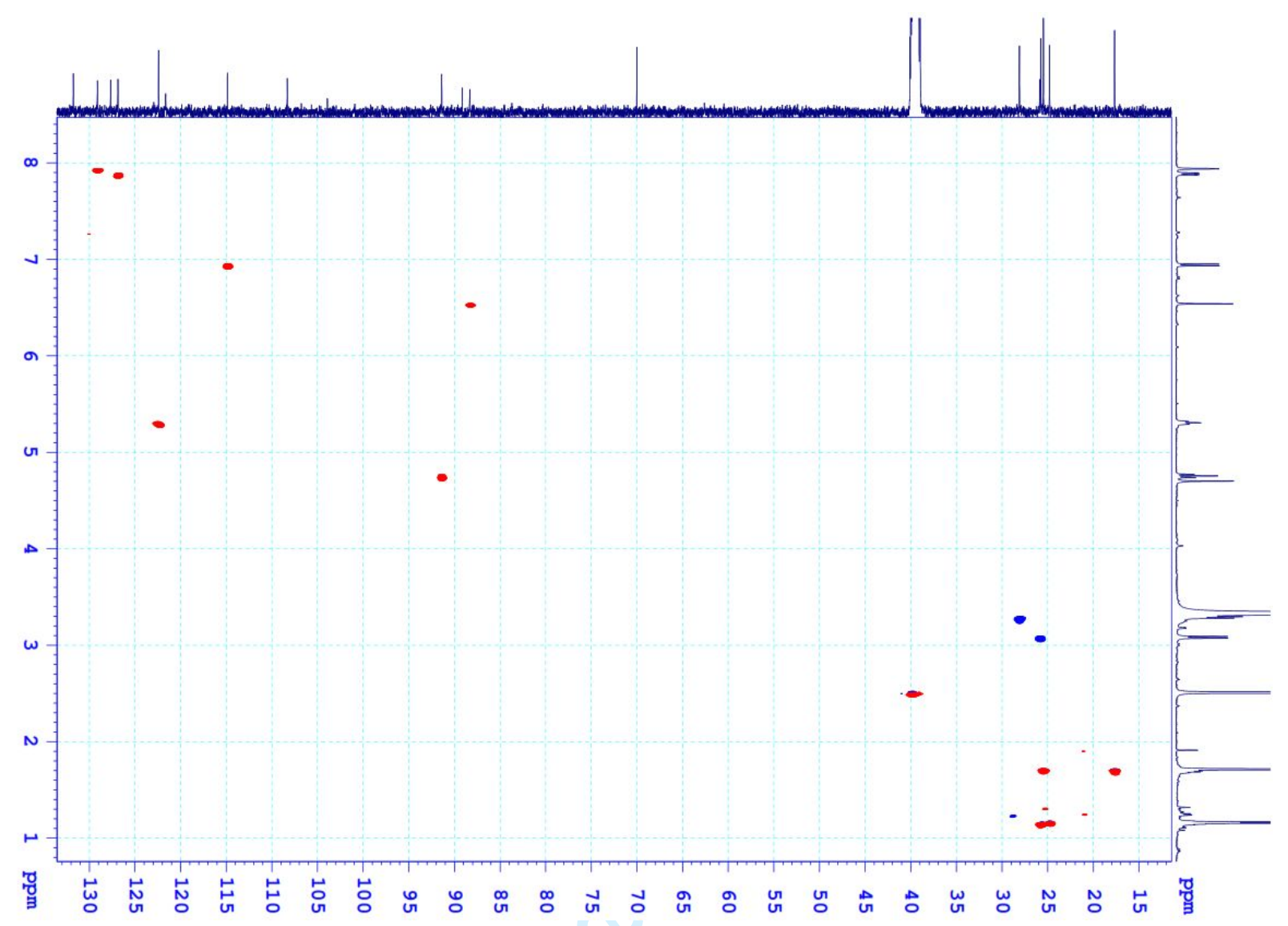

25. HMBC spectrum of compound 4

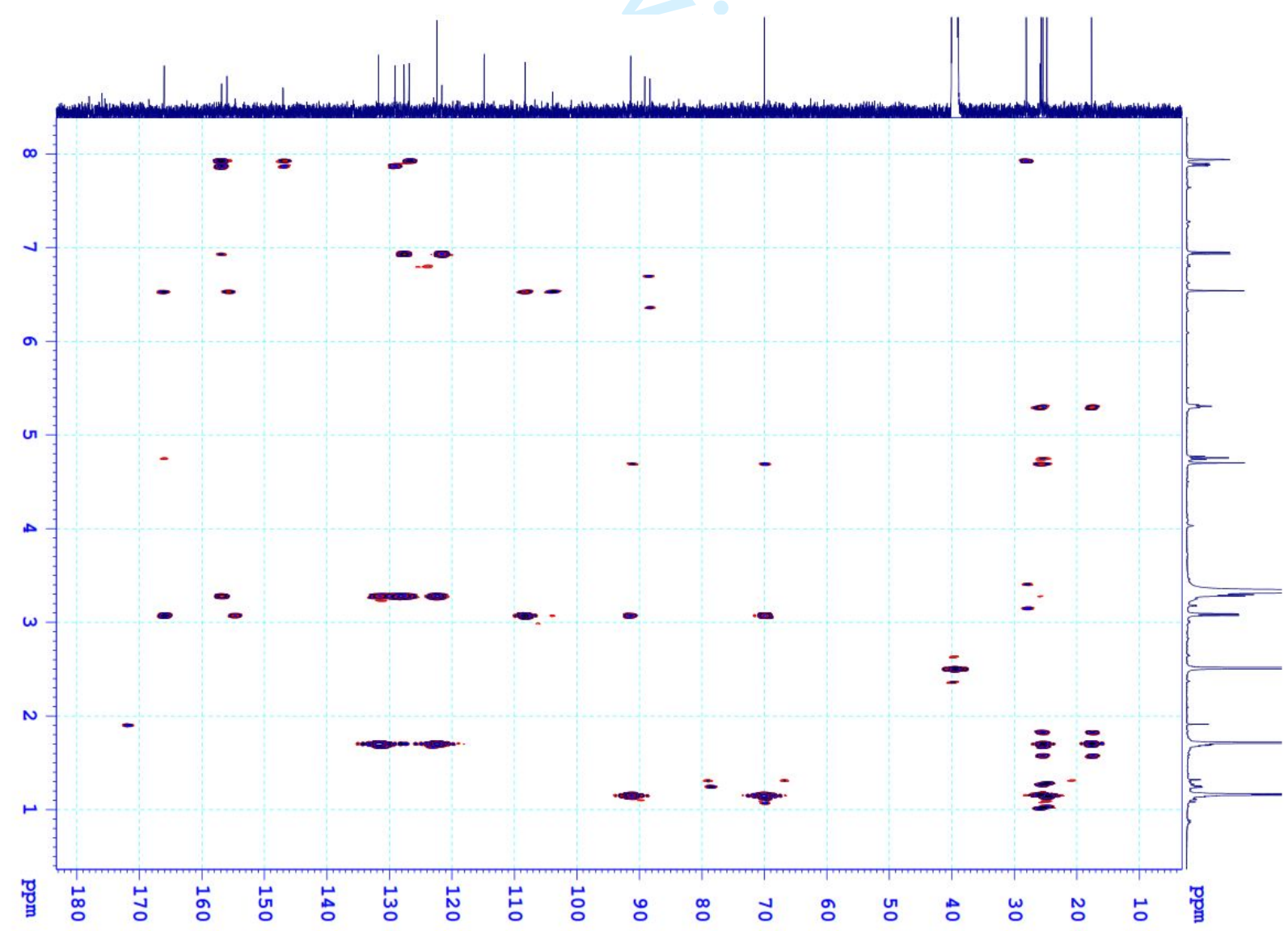


26. CD spectrum of compound 4

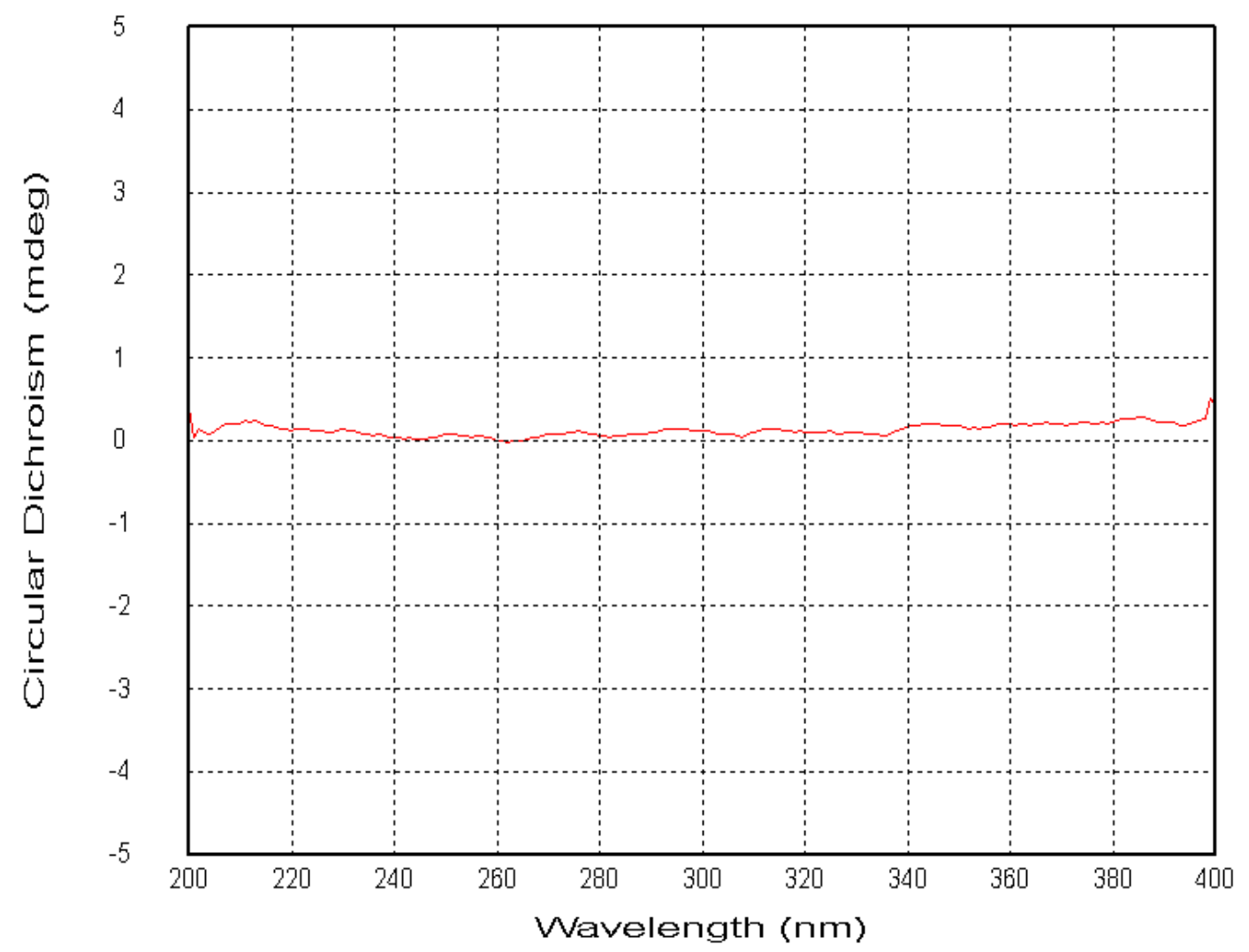

